\title{
KEBEBASAN HAKIM MEMUTUS PERKARA \\ DALAM KONTEKS PANCASILA \\ (DITINJAU DARI KEADILAN "SUBSTANTIF")
}

\author{
Ery Setyanegara ${ }^{1}$
}

\begin{abstract}
Indonesian law constitution in 1945 stated that Indonesia is a law country. The important things for a cuntry to get guarantee for a judges in applying their duties in the justice. The judges freedom is a judges free to solve a problem without intervene. Its' necessary, so they can give solve and judgements evaluation. Sociology Antropology law had opened our eyes in law or judgement, and not all the text could we trust as a representation in our life. Law is not only the text but also more deeper. Some community sated that "Law is taken the fact of the myth". To see human attitudes as law, so we need willingness to change the concept of law. Not only about rules but also as behaviour as long as we keep the rules, a country just provide the facilities with created law and given to the citizen. Culture are consist of values and attutudes which influenced the way of law. Here, Lawrence M. Friedmen called "Law Culture add the function as connect between law rules and attitudes rules in community". On the other side, culture is divided into two, internal legal culture and lawyer culture.
\end{abstract}

Keywords: the freedom judges, pancasila justice, the myth of the operation of law

Konstitusi hukum Indonesia pada tahun 1945 menyatakan bahwa Indonesia adalah negara hukum. Hal-hal yang penting bagi suatu negara untuk mendapatkan jaminan untuk hakim dalam menerapkan tugasnya keadilan. Kebebasan para hakim adalah hakim bebas untuk memecahkan masalah tanpa campur tangan. Ini diperlukan, sehingga mereka dapat memberikan memecahkan dan evaluasi penilaian. Hukum Sosiologi Antropologi telah membuka mata kita dalam hukum atau penilaian, dan tidak semua teks bisa kita percaya sebagai representasi dalam hidup kita. Hukum tidak hanya teks, tetapi juga lebih dalam. Beberapa masyarakat menyatakan bahwa "Hukum diambil fakta dari mitos". Untuk melihat sikap manusia sebagai hukum, jadi perlu kemauan kita untuk mengubah konsep hukum. Tidak hanya tentang aturan tetapi juga sebagai perilaku selama kita menjaga aturan, negara hanya menyediakan fasilitas dengan hukum diciptakan dan diberikan kepada warga negara. Budaya yang terdiri dari nilai-nilai dan sikap yang mempengaruhi cara hukum. Di sini, Lawrence M. Friedman menyebutkan" Budaya Hukum menambahkan fungsi untuk menghubungkan antara aturan hukum dan aturan

\footnotetext{
${ }^{1}$ Mahasiswa Program Doktor Ilmu Hukum Universitas Diponegoro Angkatan XVI, 2010. Alamat kontak:
} 
sikap di masyarakat". Di sisi lain, budaya dibagi menjadi dua, budaya hukum internal dan budaya pengacara

Kata kunci: kebebasan hakim, keadilan pancasila, mitos operasi hukum

\section{Pendahuluan}

\section{Kekuasaan Kehakiman yang Merdeka menurut Konstitusi}

Undang-Undang Dasar Negara Republik Indonesia Tahun 1945 menegaskan bahwa Indonesia adalah negara hukum. Sejalan dengan ketentuan tersebut maka salah satu prinsip penting negara hukum adalah adanya jaminanpenyelenggaraan kekuasaan kehakiman yang merdeka, bebas dari pengaruh kekuasaan lainnya untuk menyelenggarakan peradilan guna menegakkan hukum dan keadilan. Pasal 24 ayat (1) Undang-Undang Dasar Negara Republik Indonesia Tahun 1945 menegaskan bahwa kekuasaan kehakiman merupakan kekuasaan yang merdeka untuk menyelenggarakan peradilan guna menegakkan hukum dan keadilan.

Penegakan hukum pidana mengindikasikan bahwa kebebasan hakim memberikan kebebasan seluas-luasnya untuk dapat melihat suatu nilai kebenaran pada peristiwa hukum, bukan melainkan sebaliknya dipergunakan untuk melakukan suatu perbuatan yang bernilai transaksional.

Hakim di tuntut untuk menegakkan hukum dan keadilan bukan memenangkan perkara-perkara yang berorientasi pada nilai ekonomi, pragmatis, sehingga dapat mendistorsi moral, nilai etis, teks UndangUndang, pembelokan pada nilai kebenaran, logika rasionalitas yang berpijak pada penalaran hukum pada azas legalitas formal.

Dimana Hakim bebas dalam memutuskan segala putusannya tanpa ada interpensi atau campur tangan pihak lain. Seorang hakim yang sangat bebas, tidak bersifat memihak dalam menjalankan tugas memutus suatu perkara di peradilan (within the exercise of the judicial function). ${ }^{2}$ Kebebasan hakim merupakan kewenangan penting yang melekat pada individu hakim dimana hakim berfungsi sebagai penerapan teks UndangUndang kedalam peristiwa yang kongkrit, tidak sekedar sustantif, tetapi juga memberikan penafsiran yang tepat tentang hukum dalam rangka meluruskan peristiwa hukum yang kongkrit sehingga Hakim dapat bebas memberikan penilaian-penilaian dan penafsiran hukumnya.

\footnotetext{
${ }^{2}$ Oemar Seno Adji, "Peradilan Bebas Negara Hukum”, (Jakarta: Erlangga, 1980), hal. 167, 253. Lebih lanjut Seno Adji menyebutkan ada tiga ciri khusus konsepsi Negara Hukum, yaitu (1) Pengakuan dan perlindungan Hak Asasi, di bidang Politik, Hukum, Sosial Ekinomi, Budaya dan Pendidikan, (2) Legalitas, dalam arti Hukum dalam segala bentuk, (3) Pengadilan Bebas, tidak bersifat memihak, bebas dari segala pengaruh kekuasaan lain.
} 
Praktek penegakan hukum pidana mulai bergeser dengan terlihat adanya gejala berfikir hukum yang parsial yang melihat UndangUndang/ketentuan dengan menggunakan kacamata kuda. Dimana seorang hakim terkesan sangat kuat menerapkan KUHP warisan Belanda secara utuh.

Mengutip dalam perkuliahan Barda Nawawi Arief dalam penegakan hukum pidana (KUHP)yang warisan Belanda juga produk dibuat tahun 1881 di ibaratkan mobil tua yang dikendarai oleh pengemudi yang modern serta iklim kondisi modernisasi teknologi, sehingga sangatlah tidak tepat lagi karena tidak sesuai pada tuntutan atau era kemajuan zaman. Gejala kemerosotan semangat Nasiosalisme dalam penegakan hukum pidana warisan penjajah yang terbelenggu pada legalitas formal, dalam bentuk praktek penegakan hukum, sehingga membentuk kebebasan hakim yang bersifat formalistik. ${ }^{3}$

Pola pikir hakim yang masih terbelenggu legalitas formal akan menghasilkan penegakan hukum yang cenderung tidak adil yang akan menciderai rasa keadilan masyarakat, karena penegakan hukum ditegakkan berdasarkan Undang-Undang warisan penjajah, yang seharusnya berdasarkan rambu-rambu sistem hukum nasional dan hukum yang tidak tertulis/hukum yang hidup di masyarakat (the living of law). ${ }^{4}$

Salah satu sifat penting dari hukum tertulis terletak pada kekakuannya (Lex dura sed tamen scripta - hukum itu keras/kaku, tetapi begitulah sifat tertulis itu). Begitu hukum itu dituliskan atau menjadi dokumen tertulis, maka perhatian bergeser pada pelik-pelik penggunaannya sebagai sebuah dokumen tertulis. Apabila berhukum itu semula berkaitan dengan masalah keadilan atau pencari keadilan, maka kita sekarang dihadapkan kepada teks, pembacaan teks, pemaknaan teks, dan lain-lain.

Berhukum yang didasarkan pada teks memiliki kecenderungan kuat untuk berhukum secara kaku dan regimentatif. Cara berhukum yang

\footnotetext{
${ }^{3}$ Barda Nawawi Arief. Mengusung Nilai-Nilai Keadilan dalam Konsep KUHP Baru. Makalah Power point. UNNES. Semarang. 2010. Kebebasan hakim yang bersifat formalistik, yaitu kebebasan hakim dalam mengadili terikat undang-undang untuk menerapkan secara subsumtif (tekstual/harfiah) sesuai ajaran La Bouce de La Loi. Lihat Sudikno Mertokusumo, "Bunga Rampai Ilmu Hukum", (Yogyakarta: Liberty, 1984), hal.30. Kebebasan hakim formalistik merupakan antitesis kebebasan hakim relistik, yang memberikan kebebasan hakim untuk menerapkan undang-undang sesuai dengan kebutuhan dan kepentingan masyarakat dalam pembangunan ini.

${ }^{4}$ Mahfud MD menyatakan bahwa penegakan keadilan saat ini menghadapi masalah besar karena rasa keadilan hampir tidak ada dan tidak lagi bersifat keadilan substantif. Hukum tidak lagi berdasarkan hati nurani, tetapi hanya terikat pada pasal-pasal formal undang-undang. Mahfud MD dalam <http//www.voa-islam.com/news/Indonesia>, lihat juga di $<$ http//:nasional.kompas.com.read>, Mahfud mendesak agar penegak hukum mendahulukan keadilan substantif dalam memutuskan perkara pidana. Penegakan persoalah hukum saat ini timbul, ketika penegak hukum langsung memberlakukan bunyi teks undang-undang pada orang-orang kecil yang berurusan dengan hukum.
} 
demikian itu, apalagi yang sudah bersifat eksesif akan menimbulkan berbagai persoalan yang besar, khususnya dalam hubungan dengan pencapaian keadilan. Apabila kita mengatakan bahwa hukum itu cacat sejak lahir maka penyabab cacat tersebut karena kita merumuskan sebuah substansi, ide, kedalam kalimat, kata-kata atau bahasa. ${ }^{5}$

Kita juga mengenal praksis "penghalusan hukum" (rechtsverfijning) yang juga bertujuan untuk menggunakan ketentuan yang bersifat umum itu secara lebih tepat dan adil.

Beberapa praktisi dalam pemikir hukum, seperti hakim Agung Oliver Wendell Holmes yang legendaris itu, dari sekali ketidak adilan yang akan muncul dari penerapan rumusan yang umum atau teks-teks itu secara begitu saja. Maka keluarlah Diktum Holmes yang terkenal, "The life of the law has not been logic: it has been experience".

Banyak hal yang tidak terwadahi dalam teks tertulis, seperti suasana dan kebutuhan-kebituhan yang ada pada suatu saat, karena moral yang dipeluk masyarakat pada suatu kurun waktu tertentu, tidak mungkin terekam dalam teks tersebut. Menurut Holmes hukum itu juga merupakan endapan dari pengalaman sejarah suatu bangsa selama berabad-abad, sehingga hukum tidak boleh digarap menggunakan silogisme. "It can't be dealt with as if it contained only the oxioms and colloraries of a book of mathematics".

Sosiologi hukum dan kemudian antropologi hukum yang membuka mata kita terhadap peran manusia dalam berhukum. Hukum yang oleh positivis dilihat sebagai teks dan mengeliminasi faktor serta peran manusia, mendapatkan koreksi besar dengan menempatkan peran manusia tidak kurang pada posisi sentral. Ternyata teks-teks hukum itu tidak dapat sepenuhnya dipercaya sebagai representasi kehidupan hukum yang otentik. Sewaktu Sabastian Pompe mulai penelitiannya mengenai lima puluh tahun Mahkamah Agung RI, ia kira cukup melakukan studi dokumen. Ternyata itu sama sekali tidak cukup, sehingga harus berpindah melakukan studi secara sosiologis. Whilts this study originally strarted out the using formal legal approach therefore, the shortcomings of legal analys and its inadequacy as an analytical tool where soon apparent. Pompe mengeluh bahwa dengan cara mempelajari dokumen formal ini tidak dapat mengungkap kenyataan tentang MA yang begitu kaya ("... could not be explained with reference to statue or court decisions").

Apabila kita mulai memindahkan fokus studi ke lapangan atau ranah empiris, maka muncul perilaku manusia sebagai hukum. Ditentukan, bahwa peran manusia dalam bekerjanya hukum terlalu besar untuk diabaikan. Hukum bukan apa yang di tulis dan dikatakan oleh teks bahkan sebagian orang mengatakan bahwa hukum itu lebih merupakan hal. 10 .

${ }^{5}$ Satjipto Rahardjo, “Penegakan Hukum Progresif”, (Jakarta: Penerbit Kompas, 2010), 
mitos dari kenyataan. The myth of the operation of law is given the lie daily.

Untuk dapat melihat perilaku manusia sebagai hukum maka diperlukan kesediaan untuk mengubah konsep kita mengenai hukum yaitu tidak hanya sebagai peraturan (rule) tetapi juga sebagai perilaku (behavior). Selama kita bersikukuh, bahwa hukum itu adalah peraturan dan tidak ada yang lain maka sulitlah untuk memahaminya.

Hukum sebagai teks itu diam dan hanya melalui perantaraan manusialah ia menjadi hidup. Dalam pustakaan sosiologi hukum perantaraan seperti itu disebut mobilisasi hukum. Perilaku atau tindakan manusia itu dapat menambah dan mengubah teks. Penegakan hukum (law and forcement) adalah konsep normatif, dimana orang hanya tinggal mengaplikasikan apa yang ada dalam perundang-undangan.

Sosiologi hukum menemukan bahwa peran perilaku manusia adalah jauh bervariasi dan tidak semata-mata sebagai mesin otomat. Roger Cotterrel menggunakan istilah the invocation of law Menurut Cotterrel negara hanya menyediakan fasilitas melalui pembuatan hukum dan untuk selebihnya diserahkan kepada rakyat. ${ }^{6}$

Metode lain untuk mencegah kejahatan, adalah membuat ketaatan atas hukum,dan bukan suatu pelanggarannya menjadi kepentingan hakim

\section{Konsep Mengadili dan Memutus Perkara Pidana dalam Nilai-Nilai Pancasila}

\section{Kebebasan Mengadili dalam Konsepsi Pancasila}

Tugas pokok hakim dalam mengadili perkara pidana adalah melakukan kegiatan yuridis sendiri tidak sekedar melakukan silogisme belaka. Hakim ikut serta dalam pembentukan hukum, bukan pula secara objektif seperti yang diciptakan pembentuk undang-undang yang abstrak, tetapi menerapkan teks Undang-Undang yang abstrak kedalam peristiwa kongkrit. Proses menerapkan teks Undang-Undang yang bersifat umum dan abstrak ke dalam peristiwa yang kongkrit perkara hukum pidana, pada hakikatnya merupakan kegiatan membaca dan menafsirkan teks Undang-Undang yang bersifat umum dan abstrak kedalam peristiwa kongkrit. Penafsiran hukum merupakankegiatan yang mutlak terbuka untuk dilakukan, sejak hukum di konsepkan sebagai teks undang-undang tertulis, sehingga muncul adagium "membaca hukum adalah menafsirkan hukum". 7

\footnotetext{
${ }^{6}$ Satjipto Rahardjo, Op. Cit., hal. 13-15.

${ }^{7}$ Satjipto Raharjo, “Hukum dalam Jagat Ketertiban”, (Jakarta: UKI Press, 2006), hal.
} 163. 
Tugas hakim yang berkaitan dengan penerapan teks undang-undang ke dalam peristiwa kongkrit peristiwa perkara pidana sebagai kegiatan penafsiran hukum disinilah terletak kebebasan hakim. Kegiatan menafsirkan teks undang-undang ke dalam peristiwa kongkrit pada hakikatnya merupakan kegiatan penilaian hukum, yaitu produk proses pemaknaan akal - budi dan hati nurani terhadap hasil persepsi manusia tentang situasi kemasyarakatan dalam kerangka pandangan hidup, keyakinan keagamaan dan keyakinan etis dengan nilai-nilai yang di anut. Kegiatan penilaian hukum mencari nilai-nilai dan makna yang tersembunyi dalam teks undang-undang, yaitu nilai-nilai justice, utility, dolmatigheid, bilijkheid, sehingga setiap kali membaca teks peraturan, maka harus mencari makna lebih dalam yang ada di belakang peraturan tersebut. $^{8}$

Kebebasan hakim dapat di uji ke dalam dua hal, yaitu: ketidakberpihakan (impartiality) dan keterputusan relasi dengan para aktor politik (political insularity). ${ }^{9}$ Prinsip ketidakberpihakan hakim akan tercermin dalam argumentasi hukum dan putusan yang tidak ada relasi kepentingan dengan perkara, sedangkan prinsip keterputusan dengan aktor politik akan tercermin dari daya laku putusan yang adil dan diterima masyarakat pencari keadilan.

Penilaian hukum sebagai proses pemaknaan akal budi dan hati nurani manusia terhadap teks undang-undang terhadap peristiwa kongkrit yang dijalankan hakim, melibatkan perspektif pemikiran dan hati nurani yang bersifat individual. Kebebasan hakim dalam menafsirkan hukum merupakan kegiatan yang bersifat individual. Kebebasan hakim sebagai ekspresi intelektual dan moral yang bersumber dari individu hakim memerlukan persyaratan kompetensi dan integritas tinggi dalam rangka menggali makna-makna tersembunyi di balik teks undang-undang. Terdapat beberapa persyaratan untuk menjamin kompetensi dan integritas hakim agar tetap dipercaya masyarakat; Pertama, sejauhmana hakim bisa bekerja dengan objektif, apakah hakim yang di konstruksikan sebagai manusia bebas (kebebasan hakim) tidak bias atau berat sebelah, dan apakah senantiasa berpihak pada kebenaran. Kedua, apakah benar hakim yang baik, secara sadar atau tidak sadar tidak akan di pengaruhi sikap prejudice, disebabkan latar belakang sosial politiknya ketika memutus perkara, padahal seharusnya bersikap objektif dan imparsial. Ketiga apakah sikap bias di pengaruhi cara hakim dalam memahami kedudukan dan fungsinya, karena setiap mengadili perkara akan terjadi pro dan kontra. ${ }^{10}$

${ }^{8}$ Ibid., hal. 169.

9 A. Muhammad Asrun, "Krisis Peradilan: Mahkamah Agung di bawah Suharto", (Jakarta: ELSAM, 2004), hal. 45. 
Kebebasan hakim dalam mengadili, pada dasarnya bisa di golongkan pada pengertian kebebasan yuridis sebagai kebebasan yang bersumber dari hak-hak manusia yang dijamin hukum. Kebebasan yang bersumber dari hak-hak manusia, pada umumnya selalu berkaitan dengan kewajiban manusia. Kebebasan yang sejati adalah kebebasan yang bersinggungan dengan keterikatan pada norma-norma, sehingga norma-norma hakikatnya bukanlah penghambat kebebasan, tetapi menegaskan makna kebebasan yang lebih bernilai etis. ${ }^{11}$ Kebebasan adalah hak nilai dasar manusia sebagai lambang martabat manusia. Kesadaran bahwa kebebasan adalah sebuah nilai, menuntut bahwa setiap pembatasan terhadap kebebasan harus bisa di pertanggung jawabkan. ${ }^{12}$

\section{Kebebasan Memutus dalam Konsepsi Pancasila}

Kebebasan hakim merupakan derivasi prinsip independensi pengadilan. Independensi pengadilan dibedakan secara luas dan sempit. Independensi pengadilan dalam arti sempit bahwa kekuasaan pengadilan sebagai bagian kekuasaan kehakiman digolongkan "independensi institusional/struktural". Dalam arti luas independensi kekuasaan kehakiman (pengadilan) merupakan "independensi individual". Independensi individual/personal di bedakan; (1) Independensi persoanal, yaitu independensi hakim terhadap sesama hakim koleganya, (2) Independensi susbtantif merupakan independensi dari pengaruh semua pihak baik dalam memutuskan perkara pidana atau kedudukannya sebagai hakim yang di jamin undang-undang. ${ }^{13}$

Secara prosesual di pengadilan, kebebasan peradilan yang dijalankan hakim dalm mengadili, mengandung pengertian pembatasan juga. Hakim dalam proses mengadili perkara di pengadilan, kebebasannya tidaklah bersifat mutlak. Batasan kebebasan hakim ada dalam UUD 1945, Undang - Undang, hukum yang tidak tertulis dan kepentingan para pihak hukum yang berperkara. Tidak boleh dilupakan Pancasila, sebagai sumber dari

${ }^{10}$ Jimly Assidhiqie, dalam Luhut Pangaribuan, "Lay Judges \& Hakim Ad Hoc, Studi Teoritis mengenai Sistem Peradilan Pidana Indonesia", (Jakarta: Penerbit Papas Sinar Sinanti, 2009), hal. 188.

11 K. Bertens, "Etika", (Jakarta: Gramedia Pustaka Utama, 2000), hal. 102, 104. Sedangkan Frans Magnis - Suseno menggunakan istilah Kebebasan Normatif, yaitu keadaan yang dialami manusia tidak berada dalam paksaan. Lihat Frans Magnis - Suseno, "Etika Dasar, Masalah-masalah Pokok dalam Filsafat Moral”, (Yogyakarta: Penerbit Kanisius, 1985), hal. 30 .

12 Andre Atta Ujan, "Filsafat Hukum, Membangun Hukum, Membela Keadilan", (Yogyakarta: Pustaka Filsafat. Kanisius, 2009), hal. 126.

13 J. Djohansjah, Reformasi Mahkamah Agung Menuju Independensi Kekuasaan Kahakiman, dalam Luhut Pangaribuan. "Lay Judges \& Hakim Ad Hoc, Studi Teoritis Mengenai Sistem Peradilan Pidana Indonesia”, (Jakarta: Fakultas Pascasarjana Universitas Indonesia, 2009), hal. 189. 
segala sumber hukum yang kecuali memungkinkan kebebasan bagi hakim dan menafsirkan undang-undang, juga membatasi hakim dalam menjalankan tugasnya agar tidak bertentangan dengan Pancasila. ${ }^{14}$

Batasan atau rambu-rambu yang harus di perhatikan dalam implementasi kebebasan hakim, terutama berkaitan dengan aturan-aturan hukum. Batasan aturan hukum terhadap kebebasan hakim dalam mengadili baik segi prosedural dan substansial - material, merupakan batasan kekuasaan kehakiman agar indenpendensinya tidak melanggar hukum, bertindak sewenang-wenang. Hakim adalah "subordinated" pada hukum dan tidak dapat bertindak "contra legem". Kebebasan hakim juga terikat pada tanggung jawab atau akuntabilitas, karena antara tanggung jawab dan akuntabilitas seperti kedua sisi koin mata uang yang saling melekat. Kebebasan hakim (independency of judiciary) haruslah di imbangi dengan pasangannya yaitu akuntabilitas peradilan (judicial accountability). Bentuk tanggung jawab peradilan adalah "Sosial Accountability”, karena badan kehakiman melaksanakan Public Service di bidang keadilan. ${ }^{15}$ Konsep independensi peradilan yang dijalankan hakim, pada umumnya selalu dikaitkan dengan konsep akuntabilitas, sebagai sarana keterbukaan menerima kritik dan kontrol dari luar serta kesadaran yang bertanggung jawab. ${ }^{16}$

Rambu-rambu hukum sebagai landasan yuridis dan moral penegakan hukum dan keadilan merefleksikan sistem hukum nasional (National Legal Framework), bahkan dalam konteks Pembangunan Nasional (Bangnas) dan Pembangunan Hukum Nasional (Bangkumnas), maka inilah baru dapat dikatakan "Penegakan Hukum di Indonesia". Penegakan hukum pidana positif harus selalu berada dalah konteks ke Indonesiaan. ${ }^{17}$

Kebebasan hakim dalam mengadili perkara pidana yang bertujuan untuk menghasilkan putusan yang adil dan di terima masyarakat perlu mendapat jaminan perlindungan, agar tidak ada intervensi kekuasaan dan kepentingan. Putusan yang di buat dengan landasan rasionalitas argumentasi hukum yang objektif dan kandungan etis moral yang kuat, dapat dipertanggung jawabkan kepada masyarakat pencarikeadilan. Jaminan hukum terhadap kebebasan hakim dalam menjalankan tugas peradilan (within the exercise of the juditial function), diatur dalam Konstitusi Negara dan undang-undang. ${ }^{18}$ Pengaturan kebebasan hakim

${ }^{14}$ Sudikno Mertokusumo. 1983. Loc. Cit. hal. 212.

15 Paulus Efendi Lotulung, Kebebasan Hakim dalam Sistem Penegakan Hukum. Makalah dalam Seminar Pembangunan Hukum Nasional VIII, BPHN. Denpasar, Bali, 2003.

${ }^{16}$ Muchsin, "Kekuasaan Kehakiman yang Merdeka dan Kebijakan Asasi”, (Jakarta: Penerbit STIH IBLAM, 2004), hal. 10.

${ }^{17}$ Ibid., hal. 59. 
dalam mengadili juga diatur dalam konvensi Internasional, menjamin kebebasan hakim dalam mengadili dan imunitas dari segala tuntutan hukum. ${ }^{19}$ Jaminan hukum terhadap kebebasan hakim dalam mengadili yang bersumber dari asaa-asas peradilan, yaitu Ius Curia Novit (hakim di anggap tahu hukum), Res Judicata Pro Varitate Habetur(putusan hakim di anggap benar). Sedangkan dalam mengadili, hakim dibebaskan dari segala tuntutan hukum, apabila hakim di anggap melakukan kesalahan teknis yuridis, bukan etik moral.

Jaminan terhadap kebebasan hakim dalam mengadili yang sangat memadai dalam konstitusi dan peraturan perundang-undangan, sudah seharusnya di pergunakan secara proporsional, jangan menonjolkan sikap arrogance of power, memperalat kebebasan untuk menghalalkan cara, maka di gunakan dengan acuan :

1) Menerapkan hukum yang bersumber dari peraturan perundangundangan yang tepat dan benar dalam menyelesaikan kasus perkara yang sedang di periksanya, sesuai dengan asas dan status law must prevail(ketentuan undang-undang harus di unggulkan)

2) Menafsirkan hukum yang tepat dengan cara-cara pendekatan yang dibenarkan (penafsiran sistematic, sosiologis, bahasan analogis dan a contrario) atau mengutamakan keadilan dari pada peraturan perundang-undangan, apabila ketentuan undangundang tidak potensial melindungi kepentingan umum. Penerapan yang demikian sesuai dengan doktrin equity must prevail (keadilan harus di unggulkan)

${ }^{18}$ Lihat Pasal 24 UUD’45 (amandemen ketiga) dan Pasal 1 Ayat (1) UU. No. 48 tahun 2009 tentang Kekuasaan Kehakiman. Lihat pula Surat Edaran Ketua Mahkamah Agung RI Nomor 09 tahun 1976 tentang Gugatan terhadap Pengadilan dan Hakim, substansi pokok surat edaran tersebut, bahwa Hakim bebas dari Gugatan ganti rugi karena kesalahan dalam tugas mengadili.

${ }^{19}$ Lihat Basic Prinsiples on the Independence of the Judiciary (Seventh United Nation Conggress on the Prevention of Crime and the Treatment of offender held at Milan from 26 August to 6 September 1985 and endorse by General Assembly Resolutions 40/30 of 29 November 1985 and 40/146 of 13 Desember 1985). Pernyataan tentang jaminan kebebasan hakim dalam mengadili: Independence of Judiciary; the independence of the judiciary shall be guaranted by the state and in the constitution or the law of the country. It is the duty of all governmental and other institution to respect and observe the independence of the judiciary. Sedangkan imunitas hakim dinyatakan: "without or complaint made against a judge in his/her juditial professional capacity shall be processed expeditiously and fairly under an approciate proccedure. The judge shall have the right fair hearing. The examination of the matter at its initial stage shall be kept confidential, unless, otherwise requested by the judge. Pengarturan kebebasan hakim juga di atur dalam The Bangalore Principle of Judicial Conduct (The Bangalore Draft Code of Judicial Conduct 2001 adopted by Judicial Group on the Strengthening Judicial Integrity, as revised at the Round Table Meeting Of Chief Justices held at the Peace Palace, The Hague, November 25 - 26, 2002). Pernyataan tentang Kebebasan Hakim antara lain: a Judge shall exercise the juditial function independently on the law, free of any axtraneous, influence, inducements, pressures, threat of interference, direct or indirect, from any quarter or any reason. 
3) Kebebasan untuk mencari dan menemukan hukum (rect vinding), dasar-dasar dan asas hukum memalui doktrin ilmu hukum, norma hukum tidak tertulis (hukum adat), yurisprudensi maupun melaui pendekatan "relisme" yakni mencari dan menemukan hukum yang terdapat pada nilai ekonomi, moral, agama kepatuhan dan kelaziman. ${ }^{20}$

\section{Perlakuan yang sama dimuka Hukum dalam Konsepsi Keadilan Pancasila (equality before the law)}

Data dan fakta saat ini menunjukan bahwa sistem dan praktek berhukum kita sedang mengalami masalah serius yang kemudian berakibat pada rendahnya tingkat kepercayaan masyarakat terhadap institusi penegak hukum. Praktek-praktek penegakan hukum yang berlangsung, meskipun secara formal telah mendapat legitimasi hukum (yuridis - formalistik) namun legitimasi moral dan sosial sangat lemah.

Secara konstitusional sebagaimana disebutkan dalam UUD 1945 pasal 28D "Setiap orang berhak atas pengakuan, jaminan, perlindungan dan kepastian hukum yang adil serta perlakuan yang sama di hadapan hukum. 'Dasar konstitusi ini sangatlah jelas setiap negara memiliki hak dan perlakuan yang sama di muka hukum. Tidak ada deskriminasi dalam proses penegakan hukum. Negara, dalam hal ini aparat penegak hukum memiliki kewajiban dalam memberikan keadilan hukum yang tidak diskriminatif. Baik untuk orang besar yang berkuasa mauppun untuk orang kecil yang tidak memiliki akses politik, kekuasaan dan ekonomi.

Keadilan hukum bagi hak masyarakat harus dijamin dan di lindungi oleh negara. Hak untuk mendapatkan keadilan hukum sama derajatnya dengan hak masyarakat untuk mendapatkan keadilan sosial, politik dan ekonomi. Namun dalam praktiknya masyarakat miskin, masih sulit untuk mendapatkan akses terhadap keadilan hukum. Akses tersebut adalah jalan yang dilalui oleh masyarakat untuk menggapai keadilan di luar maupun di dalam pengadilan.

Aturan normatif tersebut tidak seindah praktik di lapangan. Proses penegakan hukum yang seharusnya mampu melahirkan keadilan hukum. Kelompok masyarakat yang paling rentan dan sering menjadi korban ketidak adilan hukum ini adalah masyarakat yang masuk kategori lemah dan miskin. Sebaliknya proses hukum lebih cenderung berpihak pada sekelompok kecil masyarakat yang memiliki akses dan kekuatan ekonomi dan politik kekuasaan.

Sebagian masyarakat memahami hukum sekedar seperangkat peraturan positif yang tercabut dari aspek filosofis dan sosiologis, sehingga gambar hukum tampil tidak utuh, melainkan sebuah fragmen atau skeleton, yakni peraturan perundang-undangan saja. Akibatnya

20 Yahya Harahap, "Kedudukan Kewenangan dan Acara Peradilan Agama", (Bandung: Sinar Grafika, 1996), hal. 23. 
muncul kasus yang mencerminkan kondisi bahwa keadilan substantial tereliminasi dari hukum. Hukum tidak membantu, bahkan menciderai keadilan masyarakat. Fenomena peradilan terhadap "wong cilik" (the poor) misalnya :

1) Kasus pencurian satu buah semangka (di Kediri), Cholil dan Basar Suryanto di pidana 15 hari percobaan 1 bulan;

2) Kasus pencurian kapuk randu seharga 12.000 (4 anggota keluarga (Manisih, 2 anaknya dan sepupunya ditahan di LP Rowobelang Batang) dan para terrdakwa di pidana penjara 24 hari.

3) Kasus Klijo Sumarto (76) kasus pencurian setandan pisang klutuk mentah seharga Rp. 2000 di Sleman, 07 Desember 2009 (mendekam di LP Cebongan Sleman).

4) Kasus mbah Minah (di tuduh mencuri 3 biji kakao seharga Rp. 2100; 02 Agustus 2009 di Purwokerto, di pidana percobaan 1 bulan 15 hari).

5) Kasus Lanjar Sriyanto (Karanganyar) yang di dakwa menyebabakan kematrian istrinya karena kecelakaan motor di Karanganyar, dalam kasus ini sangat tragis karena istrinya meninggal dunia dan dia sendiri (Lanjar) ditahan.

6) Kasus Aspuri tentang pencurian sehelai kaus tetangganya seharga Rp. 10.000,- di tahan pada bulan November 2009. ${ }^{21}$

Hukum layaknya pisau. Dia tajam kebawah, menjerat yang miskin, sebaliknya tumpul keatas, tidak berdaya jika berurusan dengan mereka yang berkuasa atau memiliki kapital. Persepsi masyarakat ini menemukan relevansinya ketika kita melihat realitas praktik penegakan hukum yang terjadi di masyarakat akhir-akhir ini.

Bandingkan dengan kasus mega skandal Bank Century Rp. 6,7 triliun yang melibatkan para pejabat tinggi yang sudah "divonis" secara politik oleh DPR, proses hukumnya berlarut-larut bahkan saat ini mengalami stagnan.

Kasus mbah Minah, Basyar - Kholil sangat mirip dengan kisah pencuri dalam novel Les Miserables karya Victor Hugo yang disadur Soetandyo (2002) dalam bukunya Hukum, Paradigma, Metode, dan Dinamika Masalahnya. Menurut Soetandyo, apabila di lihat dari kaca mata ilmu hukum murni (jurisprudence) semata, terutama mazhab yang lebih menitik beratkan pada seni menemukan dan menerapkan aturanaturan dalam suatu kasus (in concreto) yang dikenal dengan mazhab positivisme, ${ }^{22}$ si pelaku pencuri jelas bersalah telah melakukan pencurian

21 Suteki. Kebijakan Tidak Menegakan Hukum (Non Enforcement of Law), demi Pemuliaan Keadilan Substantif. Naskah Pidato Pengukuhan Penerimaan Guru Besar dalam Ilmu Hukum Fakultas Hukum UNDIP. Semarang. 2010, hal. 5 - 6. 
walaupun dilakukannya secara terpaksa walaupun tidak ada motivasi sedikitpun untuk memperkaya diri (crime by need). Tetapi ababila dilihat dari kacamata sosiologi hukum, maka kisah kasus tersebut bisa bermakna lain. Sosiologi tidak berhubungan dengan law aswhat ought to be, tetapi berurusan dengan pertanyaan law as what is it in (functioning) society. Pemahaman dan penerapan hukum yang kering dan kajian sosiologis tidak akan memberikan rasa keadilan bagi masyarakat, justru yang terjadi adalah ketidakadilan.

Proses peradilan pidana dalam penanganan kasus diatas, menampakkan cara hukum yang masih menganut ajaran silogisme, yaitu pandangan hukum yang legistis, hukum di identikkan dengan undangundang atau hukum sama dengan undang-undang. ${ }^{23}$ Satu-satunya sumber hukum adalah undang-undang karena undang-undang dianggap lengkap dan jelas mengatur semua persoalan hukum, sehingga hakim tidak boleh berbuat selain dari menerapkan undang-undang secara tegas apa adanya. Hakim hanya sekedar corong atau terompetnya undang-undang ( $\mathrm{La}$ bouche de la loi), ${ }^{24}$ mengabaikan sama sekali hukum-hukum tidak tertulis yang meliputi hidup di masyarakat. Teks undang-undang merupakan satu-satunya sumber hukum, sehingga undang-undang menjadi sarana tafsir tunggal dalam memberikan keadilan. Keadilan sebagai produk proses pengadilan hanya sebatas keadilan formal ${ }^{25}$, yaitu

22 Mazhab Positivisme ini muncul dan mendominasi pada abad ke-19. Dengan dipelopori oleh Sosiolog Auguste Comte melalui karya "The Course of Positive Philosophy" $(1830-1842)$. Aliran positivisme mewarnai perkembangan ilmu pengetahuan, termasuk dalam pemikiran dan konsepsi-konsepsi hukum di berbagai negara. Keyakinan dasar aliran ini menyatakan bahwa realitas berada (exist) dalam kenyataan dan berjalan sesuai dengan hukum alam (Agus Salim, 2006:69). Seluruh proses pemikiran yang berawal dari suatu proposisi bahwa alam pengalaman itulah yang harus dipandang sebagai sumber segala kebenaran yang akhir dan sejati. Penganut paham ini akan senantiasa menggunakan parameter hukum positif bahkan cenderung mengagung-agungkan hukum positif untuk melakukan penilaian terhadap suatu masalah dengan mekanisme hierarki perundang-undangan. Dengan penggunaan aliran ini penegakannya mengandalkan sanksi bagi akan tercapai kepastian dan ketertiban serta mempertegas wujud hukum dalam masyarakat. Positivisme adalah suatu paham yang menuntut agar setiap metodologi yang di pikirkan untuk menemukan kebenaran hendaklah memperlakukan realitas sebagai sesuatu yang eksis, sebagai suatu objek, yang harus di lepaskan dari sembarang macam perkonsepsi metafisis yang subjectif sifatnya (Gordon, 1991:301, dalam Wignjosoebroto, 2002:96).

23 Sudarto, "Hukum Pidana dan Perkembangan Masyarakat, Kajian Terhadap Pembaharuan Hukum Pidana”, (Bandung: Sinar baru. Bandung, 1983), hal. 4.

${ }^{24}$ Bambang Sutiyoso, "Metode Penemuan Hukum, Upaya Mewujudkan Hukum Yang Pasti Dan Berkeadilan”, (Yogyakarta: UII Press, 2006), hal. 56.

${ }^{25}$ Putusan pengadilan yang menggambarkan keadilan formal pada kasus pidana di atas, biasanya menyangkut orang-orang miskin (the poor) yang tidak ada akses keadilan. Keadilan formal di bangun atas dasar argumentasi deduksi - logis teks undang-undang terhadap fakta hukum, sehingga keadilan formal identik dengan keadilan undang-undang, kering dari nilai etis masyarakat. 
keadilan yang di bangun atas landasan logika deduksi teks undangundang.

Penegakan hukum pidana yang berlandaskan kepada hukum yang hidup dalam masyarakat (Living Law/Local Wisdom), merupakan usaha untuk menghasilkan keadilan materiil ${ }^{26}$ karena keadilan bersumber dari realitas hukum yang ada dalam masyarakat. Keadilan menjadi cermin nilai etis moral yang berbasis pada kosmologi kehidupan masyarakat. Landasan hukum yang ada pada Living Law/Local Wisdom dalam proses penegakan hukum pidana pada dasarnya merupakan pendekatan sociolegal sebagai ciri dari aliran Sociological Jurisprudence. Konsekuensi dari aliran tersebut terhadap sistem kerja pengadilan (yang diwakili hakim) antara lain adalah :

1) Terdapat penghargaan terhadap Living Law (Local Wisdom);

2) Memberikan kebebasan hakim untuk memutus perkara pidana berdasarkan Living Law, atas dasar faham hukum nonpositivistik;

3) Melakukan inventarisasi putusan hakim yang memuat nilai-nilai hukum yang tumbuh dan berkembang dalam masyarakat sebagai pencerminan kesadaran hukum sebagai bahan hukum primer dalam pembuatan peraturan perundang-undangan serta dapat dipakai sebgai pertimbangan hakim yang lainnya;

4) Mengembangkan badan peradilan yang dapat menjadi badan yang menyelesaikan sengketa hukum antara pemerintah pusat dengan pemerintah daerah;

5) Mengembangkan public control terhadap produk perundangundangan $^{27}$

Usaha untuk mewujudkan keadilan substantif ${ }^{28}$ dalam penegakan hukum pidana di pengadilan, hanya dapat dihadirkan melalui pendekatan

\footnotetext{
${ }^{26}$ Istilah "keadilan materiil" berasal dari Suteki. Kebijakan tidak menegakkan hukum (non enforcement of law) Demi Memuliakan Keadilan Substantif, Pidato pengukuhan Guru Besar UNDIP. Semarang, 04 Agustus 2010, hal. 20. Contoh putusan pengadilan yang menggambarkan keadilan materiil adalah kasus pembunuhan dengan terdakwa Sadim bin Samin dalam Putusan Nomor 210/PidB/2005/PNKB di PN Rangkas Bitung, Banten. Terdakwa terbukti melakukan tindak pidana penganiayaan menyebabkan hilangnya nyawa orang lain, di pidana 7 bulan 8 hari, dengan tambahan sanksi adat yang telah di jatuhkan sidang adat Baduy, dengan ketentuan bahwa terpidana melaksanakan setelah selesai menjalankan pidana penjara. Hakim mempertimbangkan hukum adat dan pidana adat sebagai bagian dari keadilan bersumber hukum adat.

${ }^{27}$ Suteki, Op. Cita, hal. 24.

${ }^{28}$ Keadilan substantif dapat di definisikan sebagai the truth justice (sebenar keadilan, yaitu keadilan yang sebenarnya). Pertimbangan utama pencari keadilan substansial bukan lagi aspek formal (state law) dan materiil (living law) hukum, melainkan aspek hakikat hukum, yakni dilibatkannya pertimbangan moral, ethic dan religion.Ibid hlm.2 contohnya putusan PN Jakarta Timur No. 46/PID/78/UT/WANITA. 17 Juli 1978. Hakim Bismar Siregar menggunakan landasan etis yuridis "tujuan pemidanaan", terdakwa (Ny. Ellya Dado) terbukti
} 
Legal Pluralisme ${ }^{29}$ dengan memperhatikan state law, living law dan natural law secara simultan. Apabila dalam penegakan hukum telah mempertimbangkan natural law (moral ethic and religion), maka sebenarnya permasalah hukum telah melampaui ketiga sistem hukum dari Lawrence M. Friedmen, sebagai substance, srtucture and legal culture, melainkan pada derajat diri kesadaran manusia yang bersumber dari hati nurani, rasa rumangsane ati atau dalam bahasa filsafat disebut intuisi $^{30}$

\section{Nilai Keadilan dan Konsep Keadilan}

\section{Nilai Keadilan}

Keadilan sesungguhnya merupakan konsep relatif. ${ }^{31}$ Pada sisi lain, keadilan merupakan hasil interaksi antara harapan dan kenyataan yang ada, yang perumusannya dapat menjadi pedoman dalam kehidupan individu maupun kelompok. Dari aspek etimologis kebahasaan, kata adil berasal dari bahasa Arab adala yang mengandung makna tengah atau pertengahan. Dari makna ini kata adala kemudian di sinonimkan dengan

melanggar dakwaan primer Pasal 333 KUHP, subsidair Pasal 368 KUHP, lebih subsidair Pasal 315 KUHP, dalam pertimbangan hukum dinyatakan bahwa berdasarkan persetujuan antar pelaku dan korban, walau dakwaan terbukti korban dan terdakwa telah damai, sehingga telah di selesaikan konflik. Bahwa hakikat peradilan adalah memberikan keadilan dan mengembalikan "kegalingan" hubungan masyarakat yang terganggu, sehingga hakim tidak melihat alasan menerapkan hukum secara harfiah bahkan hukuman akan meninggalkan cacat batin. Bahwa penyelesaian secara kekeluargaan, Pengadilan patut mempertimbangkan berdasarkan Pasal 14 Ayat (1) UU No. 14 tahun 1970 (sekarang UU. No. 48 tahun 2009 Pasal 2 Ayat (1) Peradilan dilakukan "demi keadilan berdasarkan Ketuhanan Yang Maha Esa", berdasarkan perbuatan itu yang terbukti tidak lagi merupakan perbuatan yang dapat dituntut pidana, melepaskan terdakwa dari segala tuntutan hukum. Lihat Anatonius Sudirman, "Hati Nurani Hakim dan Putusannya" (Bandung: Citra Aditya Bhakti, 2007), hal. 202 dan Barda Nawawi Arief, "Pendekatan Keilmuan dan Pendekatan Religius dalam rangka Optimalisasi dan Reformasi Penegakan Hukum (Pidana) di Indonesia”, (Semarang: Badan Penerbit UNDIP, 2007), hal. 38.

29 Legal Pluralism adalah pendekatan yang ke-4 dari Werner Menski, mempertautkan state law (positive law) aspek kemasyarakatan (sosio-legal-approach) dan natural law (moral,/ethic/religion). Melalui pendekatan legal pluralism mampu dihadirkan keadilan substantif yang sempurna (perfect justice). Ibid., hal. 44.

${ }^{30}$ Ibid., hal. 20. lihat juga Barda Nawawi Arief Menyebutnya sebagai pendekatan kultural-religius, yang mengandung makna pendekatan moral dan pendekatan keilmuan (Ilmu Pengetahuan). Barda Nawawi Arief, "Pendekatan Keilmuan dan Pendekatan Religius dalam rangka Optimalisasi Pengakan Hukum (Pidana) di Indonesia", (Semarang: Badan Penerbit UNDIP, 2010), hal. 50, 53. Penegakan hukum secara utuh dan bercirikan nilai-nilai keadilan Indonesia, dengan demikian bertumpu pada ketiga pendekatan yang dijalankan secara simultan, sehungga secara substansial, penegakan hukum pidana yang berkarakter Indonesia Pada dasarnya bersumber dari Hukum Positif (Statue Law), Living Law/ Local Wisdom, dan Moral, ethic, religion / Religious Wisdom.

${ }^{31}$ Majjid Khadduri, “The Islamic Conception of Justice”, (Baltimore and London: The Johns Hopinks University Press, 1984), hal. 145. 
Wasth yang menurunkan kata Wasith yang berarti penengah atau orang yang berdiri di tengah yang mengisyaratkan sikap yang adil ${ }^{32}$.

Dari pengertian ini pula, kata adil di sinonimkan dengan inshaf yang berarti sadar, karena orang yang adil adalah orang yang sanggup berdiri di tengan tanpa apriori memihak. Orang yang demikian adalah orang yang selalu menyadari persoalan yang dihadapi itu dalam konteksnya yang menyeluruh, sehingga sikap atau keputusan yang diambil berkenan dengan persoalan itu pun menjadi tepat dan benar. ${ }^{33}$ Dalam ilmu fikh, adil merupakan sifat yang dituntut dari para saksi dalam pengadilan, sehungga kesaksiannya dapat di percaya. ${ }^{34}$

Kata adil dalam bahasa Arab adalah nomina augentie (ism failBahasa arab) yang berasal dari kata benda "adala" yang mempunyai arti:

1) Tegak lurus atau meluruskan;

2) Untuk duduk lurus atau langsung;

3) Untuk menjadi sama atau menyamakan;

4) Untuk menyeimbangkan atau bobot penyeimbang. ${ }^{35}$

Dalam bahasa Indonesia, sejauh pengetahuan penulis belum ada istilah asli untuk pengertian adil atau keadilan. Namun hal ini tidak berarti bangsa Indonesia tidak mengenal keadilan. Kesadaran akan keadilan pada dasarnya ada pada setiap manusia. Bahkan anak-anak yang masuh kecil pun menyadari dan secara naluri akan proses atau reaksi kalau mendapatkan bagian yang ebih kecil dari yang lainnya, atau sekedar menonton temannya memegang dan memainkan alat permainan tanpa diberi kesempatan untuk ikut bermain. Semua itu didorong oleh perasaan bahwa dirinya telah memperlakukan dengan tidak adil. Sementara bagi anak yang mendapatkan kesempatan memegang dan memainkan alat permainan biasanya ingin menikmati lebih lama lagi, dan itu sudah menjadi naluri nafsu keserakahan manusia.

\footnotetext{
${ }^{32}$ Adil itu sendiri dalam bahasa arab dikenal sebagai ism fa'il yang bermakna orang yang berlaku adalah atau mampu sebagai penengah.

33 Nurcholis Madjid, "Islam Kemanusiaan dan Keoderenan, Doktrin Peradaban, Sebuah Telaah Kritis Tentang Masalah Keimanan”, Cetakan kedua, (Jakarta: Yayasan Wakaf Peradaban, 1992), hal. 56.

34 Orang yang adil disamping dapat dipercaya juga berarti orang yang tidak melakukan dosa besar atau tiada biasa melakukan pelanggaran-pelanggaran (dosa-dosa) kecil. Kebalikan dari orang yang adil adalah orang yang fasik (rusak, karena dosa besar atau seringnya melakukan dosa kecil-pen). Lihat Notohamidjojo, "Masalah: Keadilan”, (Semarang: Tirta Amerts, 1971), hal. 6.

${ }^{35}$ Majjid Khadduri, Op. Cit., hal. 6. Lihat juga Ibn Manzur, "Lisan Al-Arab”, XII, hal. 457-458. Kitab Al-Misbah Al-Munir. Hal. 541-542 dan 689-690. Pengertian adil sebagai tegak lurus juga disampaikan oleh A. Rafiq. Sekretaris Majelis Umum Indonesia (MUI) Prov. Jawa Tengah dalam wawancara tanggal 6 Februari 2004. Mahmutatom HR, "Rekonstruksi Konsep Keadilan", (Semarang: Badan Penerbit UNDIP, 2009), hal. 89.
} 
Oleh karena itu dapat dikatakan, keadilan adanya bukan pada bahasa tulisan, tetapi lebih pada bahasa hati yang dapat didekati dengan niat dan itikad yang baik dan dirasakan dengan hati yang bersih. Dari contoh diatas juga dapat diketahui bahwa dalam keadilan harus ada kesediaan untuk bertenggang rasa, tidak hanya memikirkan kentingan dan kesenangan diri, kesediaan untuk berkorban, serta adanya kesadaran bahwa apapun yang dimiliki ternyata tidak mutlak miliknya. Ada hakhak orang lain di dalamnya, penggunaan terhadap apaun yang dianggap miliknya atau sesuatu yang ada dalam kekuasaannya, dengan sedemikian rupa sehingga tidak menimbulkan kerugian pada orang lain. Apalagi penggunaan fasilitas umum, pemahaman yang demikian menjadi sangat penting dalam menjaga suasana kebersamaan yang berkeadilan. Untuk dapat berlaku adil, orang harus mempunyai kemampuan berfikir dan bersikap dengan menempatkan diri seolah sebagai pihak yang berada diluar dirinya sendiri, sehingga akan ada empati yang mempunyau peran penting dalam mewujudkan makna keadilan.

Keadilan ini menjadi ruh yang mampu mengarahkan dan memberi kehidupan pada norma hukum tertulis, sehingga jika keadilan ini menjadi ruh, maka hukum tertulis itu ibarat tubuh manusia. Tanpa ruh, tubuh akan mati. Sebaliknya tanpa tubuh, kehidupan ruh tidak akan terimplikasi dalam relitas. Jika ruh dan tubuh dapat berjalan seiring, akan ada harmoni dalam kehidupan manusia, juka tidak terjadi benturan kepentingan, tidak jarang tubuh harus dikorbankan (misal tangan di amoutasi, payudara di ankat, dsb. Dalam rangka menjaga kelangsungan ruh dalam tubuh manusia. Hal ini biasa terjadi apabila benturan antara nirma dan hukum tertulisdengan keadilan, maka keadilan sebagai ruh aturan hukum tertulis itu yang harus dipertahan dan dan di aturan hukum yang tertulis itu sebenarnya hukum tertulis yang menyatakan sebenarnya dan merupakan alat mewujudkan keadilan yang dapat diganti atau di tinggalkan.

Istilah keadilan sosial yaitu keadilan yang berhubungan dengan pembagian nikmat dan beban dari suatu kerja sama sosial khususnya yang disebut Negara. Karena itu dalam literatur, keadilan sosial sering disebut juga keadilan distributif. Meski istilah tersebut tidak keliru, tapi perlu diberi catatan bahwa keadilan sosial bukan sekedar masalah distribusi ekonomi saja, melainkan jauh lebih luas mencakup keseluruhan dimensi moral dalam penataan politik, ekonomi dan semua aspek kemasyarakatan yang lain. Dalam bahasa Indonesia dikenal pula dengan ungkapan keadilan struktural yang melihat keadilan, sosial maupun individual, lebih dari perspektif struktur sosial. Keadilan sosial digunakan sebgai istilah umum, yang dalam kajian ini sering akan disingkat "keadilan" saja. Keadilan distributif dibedakan dari keadilan retributif, yaitu keadilan yang berkenaan dengan kontrol bagi pelaksanaan keadilan distributif, lebih berhubungan dengan keadilan legal atau hukum. ${ }^{36}$ 
Penghubung moral dan politik keadilan menempati posisi unik dalam filsafat dan merupakan topik utama filsafat politik. Tujuan pokok filsafat politik adalah mengevaluasi teori-teori keadilan yang saling bersaing, menilai kekuatan dan koherensi argumen-argumennya. ${ }^{37}$ Tapi keadilan juga dibahas dalam filsafat moral. Bahkan semaraknya wacana filsafat mengenai keadilan sejak awal 1980 - an lalu lebih dari sebagai bagian dari memusatnya perhatian besar terhadap etika ketimbang oleh dorongan dari wacana filsafat politik sendiri. Perhatian besar terhadap etika itu menyertai kemajuan-kemajuan luar biasa dan cepat yang dicapai berbagai bidang ilmu khususnya biologi, teknik kedokteran, teknik informasi dan telekomunikasi, fisika nuklir, serta perubahan-perubahan sosial yang telah menghadapkan umat manusia pada problem-problem etis amat serius yang belum pernah dialami sebelumnya.

Memang tidak semua filsuf bersatu pendapat dalam memposisikan keadilan dalam filsafat moral itu. Pertama, perbedaan berkenaan dengan status epistemologis pernyataan-pernyataan moral itu sendiri, yang sudah merupakan perdebatan lama dan belum terselesaikan sampai kini. Nanti akan kita lihat Habermas mencoba memberikan jawabannya mengenai perselisihan ini. Kedua, perbedaan pandangan mengenai prinsip-prinsip dasar dalam teori moral. Frankena ${ }^{38}$ melihat ada tiga prinsip dasarteori moral yang hak (the right), kewajiban (obligation), dan yang baik (the good) dan dia meletakkan keadilan dalam kerangka teori kewajiban moral normatif. Tapi John Rawls tidak melihat tiga, melainkan hanya dua prinsip dasar moral, yaitu yang hak dan yang baik. Teori-teori moral umumnya berkenaan dengan struktur hubungan antara kedua prinsip tersebut. Keadilan memang kewajiban dalam arti bukan sekedar kebaikan, belas kasihan atau semacam balas jasa. Tapi bagi Rawls keadilan juga harus dilihat dalam posisi deontologis "yang hak prioritas atas yang baik".

Jurgen Habermas melangkah lebih jauh. Bauk Frankena maupun Rawls masih menempatkan keadilan sebagai bagian dari teori moral. Tapi Habermas menganggap teori moral itu sendiri adalah teori keadilan, atau dalam bahasa Habermas: masalah keadilan koekstensif dengan maasalah moral. Habermas mengikuti Kant, membuat distingsi tegas antara etika dan moral, antar persoalan evaluatif dan persoalan normatif. Etika berkenaan dengan nilai-nilai hidup baik menurut pandangan hidup tertentu yang aneka ragam. Moral berkenaan dengan norma yang diakui bersama dan mengikat masyarakat sebagai suatu kesatuan. Norma itu adalah keadilan.

\footnotetext{
${ }^{36}$ Bur Rasuanto, "Keadilan Sosial, Pandangan Deontologis Rawls dan Habermas Dua Teori Filsafat Modern", (Jakarta: Gramedia Pustaka Utama, 2005), hal. 6.

${ }^{37}$ Will Kymlicka, "Contemporary Political Philosophy. An Introduction”, (Clarendon Press. Oxford. 1990), halm. 7-8. Selanjutnya ditulis Contemporary.

${ }^{38}$ William K. Frankena, “Ethics”, (New Jersey: Prentice-Hall, 1963), hal. 92.
} 
Yang mana pun tafsirannya, keadilan menempati posisi penghubung antara moral dan politik. Sejak Yunani klasik, filsafat moral dan filsafat politik menempati domain yang sama yang disebut filsafat praktis, yaitu bidang yang membicarakan praxix manusia, yang dibedakan dari filsafat teoretis yang menyelidiki persoalan-persoalan yang berkenaan dengan pemikiran teoretis (fisika), abstrak (logika, matematika), maupun spekulatif (metafisika). Oleh Aristoteles, politik dipahami sebagai doktrin hidup baik dan adil dalam polis. Bagi Aristoteles politik adalah lanjutan etika. $^{39}$

\section{Konsep Keadilan}

Konsep tradisional mengenai keadilan tampaknya di abaikan oleh teoriyang mengklaim "benarnya" tindakan jika dapat memaksimalkan kebaikan ini. Hak atau klaim individual di pertimbangkan berdasarkan "kebahagiaan" orang lain. Contohnya jika suatu ras yang terancam mengangkat senjata disebuah kerusuhan karena dipicu oleh gugurnya salah satu dari mereka padahal dia tidak bersalah, tampaknya kaum utilitarian akan menilai bahwa tindakan ini "benar" selama kebaikan terbesar bisa dicapai dengan cara itu, semua hak dan klaim individual bisa di abaikan. Lantaran implikasi teori utilitarian yang seperti inilah masalah keadilan terus menerus menjadi batu sandungan bagi mereka.

Baik Bentham maupun Mill menyadari implikasi semacam ini. Namun karena Bentham menganggap sistem hukuman mati lebih adil dalam kasus ini demi mengundari ketidak adilan di ruang retributifnya, kita akan lebih fokus pada Mill yang banyak membahas hubungan antara kemanfaatan dan distributive. Mill menyadari kekuatan dari perasaanperasaan yang dimiliki oleh setiap orang mengenai keadilan, dan perasaan kecewa mereka jika tidak terjadi ketidak-adilan seperti pada kasus-kasus pemberian hukuman berlebih-lebuhan terhadap orang yang tidak bersalah. Kuatnya perasaan ini membuat manusia manusia sulit melihat keadilan sebagai bagian dari kemanfaatan. Karena itu Mill berusaha mengukur apakah keadilan bersifat sui generis ataukah sebagai bagian dari kemanfaatan. Dia kemudian menyimpulkan bahwa keadilan bukan prinsip terpisah yang muncul secara independen, melainkan merupakan bagian dari kemanfaatan itu sendiri : saya menentang kemunafikan teori yang mendukung standar khayali keadilan yang tidak didasarkan kepada kemanfaatan". Dengan bertindak demikian, Mill mengikuti jejak David Hume dari dekat, karena Hume menganggap basis utilitarian sebagai prinsip keadilan yang paling berharga.

Tak seorang pun meragukan bahwa keadilan memang sangat berguna bagi masyarakat, tegas Home. Namun pernyataan yang kemudian muncul adalah apakah kemanfaatan bagi publik adalah satu-satunya asal-usul

\footnotetext{
${ }^{39}$ Bur Rasuanto. Op. Cit., hal. 9-10.
} 
keadilan. Hume menunjukan memang demikian adanya dengan membuktikan bahwa aturan-aturan keadilan tidak akan muncul pada kondisi-kondisi dimana aturan-aturan ini bermanfaat. Dalam situasisituasi kelangkaan yang ekstrim, dalam kondisi yang utamanya dicirikan oleh kebaikan atau ditempat disitu terdapat kelimpahan sehingga pemenuhan segala kebutuhan tidak di perselisihkan lagi, dalam kasus ini aturan-aturan keadilan tidak bermanfaat karena itu tidak muncul. Kemanfaatan dan kecenderungan dari luhurnya keadilan kalau begitu aturan keadilan apapun bergantung sepenuhnya pada keadaan atau kondisi khusus dimana masyarakat menemukan diri mereka sendiri. Dan semua aturan semacam ini berhutang asal-usul eksistensinya kepada asas kemanfaatan, karena melalui pengamatan yang ketat dan teratur, asas ini terbukti bisa menjawab kebutuhan public.

Hume memang tidak menawarkan definisi langsung keadilan, namun dari diskusi diatas bisa dilihat bahwa keadilan haruslah sanggup menjangkau klaim-klaim yang terpisah dan khusus mengenai kepemilikan pribadi. Didalam kondisi-kondisi kelangkaan dimana isu-isu keadilan distributf muncul, masyarakat mempunyai klaim yang terbukti bertentangan terkait kepemilikan pribadi. Dan konsep keadilan yang seperti ini, yaitu ketika menghadapi klaim-klaim yang saling bertentangan terkait kepemilikan pribadi didalam kondisi-kondisi kelangkaan, menjadi tema yang sangat berpengaruh di seluruh diskusi modern.

Mill mengadopsi konsep dasar Hume bahwa keadilan tidak muncul dari sekedar "insting asali yang sederhana di dada manusia", melainkan dari kebutuhan akan masyarakat keadilan. Kata Mill, adalah nama bagi persyaratan moral tertentu yang secara kolektif berdiri lebih tinggi di dalam skala kemanfaatan sosial karenanya menjadi kewajiban yang lebih dominan ketimbang persyaratan moral lainnya.

Langkah Mill untuk sampai pada kesimpulan ini terbagi kedalam bebrapa tahap. Pertama, menghitung bentuk-bentuk ketidak adilan dan menyelidiki kenapa muncul perasaan yang sangat kuat mengenai keadilan dan meneliti apakah perasaan tersebut dilandasi pada kemanfaatan. Kedua, mengkaji beberapa kasus kontroversial untuk menunjukan bahwa desakan terhadaap keadilan tidak akan bisa menjawab kontroveri tersebut, dimana hanya kalkulasi kemanfaatan saja yang sanggup menjawabnya.

Mill menemukan enam kondisi yang umumnya disepakati sebagai hak yang tidak adil; (1) memisahkan manusia dari hal-hal yang diatasnya mereka memiliki hak legal, (2) memisahkan dari manusia dari hal-hal yang diatasnya mereka memiliki hak moral, (3)manusia tidak memperoleh apa yang layak diterimanya, kebaikan bagi yang bertindak benar, dan kebutukan bagi yang bertindak keliru, (4) perselisihan iman diantara orang perorang, (5) bersikap setengah-setengah, contohnya menunjukan dukungan hanya sebagai pemanis bibir, (6) mengancam atau menekan orang lain yang tidak setra dengannya. Kondisi-kondisi ketidak 
adilan seperti ini tampaknya berbeda-beda. Lalu apa yang menyatukan mereka?. Konsep pembatasan legal tampaknya berlaku di dalam semuanya itu, namun Mill mencatat bahwa konsep ini juga berlaku bagi semua moralitas, "kalau begitu apa yang membedakan keadilan dari jenis kewajiban yang lan, atau dari aspek moralitas yang lain?.

Untuk menjawab pertanyaan tersebut Mill mengadopsi Distingsi Kant antara tanggung jawab terhadap kewajiban sempurna dan tanggung jawab terhadap kewajiban tidak sempurna. Tanggung jawab terhadap kewajiban melahirkan hak-hak bagi penerimanya: jika saya memiliki tanggung jawab untuk tidak menyakiti anda, anda memiliki hak untuk tidak saya sakiti. Tanggungjawab kewajiban tidak sempurna, sebaliknya tidak melahirkan hak-hak yang tidak setara: saya mertanggung jawab untuk bertindak baik, namun anda tidak memilik hak bahwa saya akan berbuat baik kepada anda. Mill menyatakan bahwa semua tanggungjawab terhadap kewajiban sempurna yang memunculkan hak-hak inilah yang menjadi arena keadilan: keadilan bukan hanya berisi apa yang benar, untuk dilakukan atau tidak benar untuk dilakukan, namun juga sesuatu yang memperbolehkan orang lainmengklaimdari kita sesuatu sebagai hak moralnya. " apa yang membedakan keadilan kalau begitu, apakah mengenai hak atau konsep itu sendiri?. Di titik ini Mill menggemakan pandangan Hume, meskipun dia tidak membatasi klaim-klaim hanya di arena kepemilikan saja. ${ }^{40}$

Karena itu bagi Mill tidak ada teori keadilan yang dipisahkan dari tuntutan kemanfaatan. Keadilan adalah istilah yang diberikan kepada aturan-aturan yang melindungi klaim-klaim yang dianggap esensial bagi kesejahteraan masyarakat, klaim-klaim untuk memegang janji diperlakukan dengan setara dan sebagainya. Klaim-klaim seperti itu adalah pokok pikiran bagi hitung-hitungan utulitarium. Kalkulasi ini bisa dilakukan jika kebaikan terbesar menuntunnya. Dengan cara yang sama, konflik apapun diantara aturan-aturan keadilan yang melindungi klaimklaim tersebut juga menjadi pokok pikiran bagi hitung-hitungan utilitarium, dan bisa di kendalikan. Keadilan bergantung pada asas kemanfaatan dan tidak bertentngan dengan asas ini. ${ }^{41}$

Sifat-sifat esensil keadilan di dalam skema utilitarian berbunyi sebagai berikut: keadilan mengakui eksistensi hak-hak individu yang didukung masyarakat. Keadilan memperbolehkan, bagi Mill mensyaratkan aturan-aturan yang ditetapkan menjadi kebaikan masyarakat demi menjamin pemenuhan kewajiban-kewajiban tertentu yang keras dan demi melindungi hak-hak individu. Keadilan bisa memadukan konsep mengenai perlakuan setara dan konsep pengabaian. Namun yang terpenting keadilan bukanlah sui generis, karena dia

${ }^{40}$ Mill, J. S, Rawl, John, “Teori-teori Keadilan Analisis Kritis terhadap Pemikiran”, (Bandung: Nusa Media, 2001), hal. 71-82.

${ }^{41}$ Ibid, , hal. 84. 
bergantung sepenuhnya pada kemanfaatan sosial sebagai fondasinya. Karena itulah semua aturan keadilan, termasuk kesetaraan, bisa tunduk kepada tuntutan-tuntutan kemanfaatan: "setiap orang yakin kalau kesetaraan adalah asas keadilan, kecuali dia berfikir metodenya mensyaratkan ketidak setaraan. Apapun membawa kebaikan terbesar bagi semuanya dapat disebut "adil". ${ }^{42}$

\section{Hakim Mengadili Menurut Hukum}

Untuk menemukan pengertian yang tepat mengenai makna "mengadili menurut hukum" sangat perlu dipahami perkembangan beberapa konsep yang mendasarinya.

Pengertian "hukum", perkataan hukum dalam asas "memutus menurut hukum" diartikan sangat luas, yaitu hukum tertulis maupun hukum tidak tertulis, termasuk juga hukum yang terlahir dari suatu perjanjian (sebagai undang-undang bagi pihak). Bahkan lebih luas lagi yaitu keharusan memperhatikan kepatutan (Pasal 1339 BW), kesusilaan dan ketertiban umum (Pasal 1337 BW).

Asas mengadili menurut hukum adalah perwujudan asas legalitas sebagai salah satu unsur pokok paham Negara berdasarkan asas hukum. Asas legalitas mengandung makna, bahwa setiap putusan hakim atau keputusan penyelenggara Negara diluar hakim atau penyelenggara pemerintahan harus didasarkan pada ketentuan hukum yang sudah ada sebelum putusan atau keputusan itu di lakukan. Pengertian hukum yang sudah ada meliputi hukum materiil (substantive) maupun hukum formal (procedural). Keharusan ada hukum sebagai dasar memutus dimaksudkan untuk mencegah hakim atau pejabat pemutus lainnya berlaku sewenang-wenang, yaitu memutus menurut kehendak sendiri yang ada pada dirinya akan menimbulkan ketidakpastian hukum.

Asas mengadili menurut hukum juga perlu dikaitkan dengan paham kodifikasi. Pada puncak pengaruh kodifikasi, berkembang teori bahwa hukum hanyalah hukum tertulis. Bahkan lebih sempit, hukum tidak lain dari pada undang-undang. Dari teori ini berkembanglah ungkapan "hakim adalah mulut atau corong undang-undang" (Spreekbuis van de wet, bouche de la loi). Menurut ungkapan ini hakim bukan saja dilarang menerapkan hukum di luar undang-undang, melainkan di larang juga menafsirkan undang-undang. Menurut paham ini menafsirkan undang-undang, bukan wewenang hakim. Pandangan ini tidak sekedar teori, melainkan pernah masuk dalam sistem hukum positif. Dalam Pasal $15 \mathrm{AB}$ ada potongan ketentuan yang berbunyi "geeft gewonte geen recht, dan allen wanner de we daarop verwijst" (ketentuan kebiasaan tidak merupakan hukum, kecuali di tinjuk oleh undangundang).

${ }^{42}$ Karen labacqz, "Teori-teori Keadilan Six Theories Of Justice”, (Bandung: Nusa Media, 2011), hal. $13-24$. 
Mengenai penafsiran hingga saat ini pun untuk sebagai paham ini masih berlaku yaitu dalam hukum acara. Masih cukup kuat pendapat pada sebagai hakim, bahwa hukum acara harus diterapkan sebagaimana adanya. Hakim dilarang menafsirkan hukum acara. Suatu cara pandang yang harus di tinjau kembali karena tidak sesuai dengan perkembangan pengertian hukum maupun praktek. Dalam praktek, Mahkamah Agung tidak lagi menjalankan paham, bahwa hukum acara tidak dapat di tafsirkan. Misalnya penerapan putusan "bebas" yang di tafsirkan menjadi "bebas murni" atau vrijspaak dan "bebas tidak murni" atau onslag van rechtsvervolging. Demikian pula penerapan putusan peradilan. Mahkamah Agung akan memeriksa permohonan kasasi peradilan dan mungkin akan mengabulkannya atas dasar fungsi pengawasan, atau kalau putusan peradilan diduga akan menghambat suatu proses peradilan (obstruction of justice) yang akan bertentangan dengan prinsip "due process of law”, begitupula dalam prosedur peninjauan kembali. Bebrapa undang-undang meniadakan upaya banding, tetapi langsung kasasi. Mahkamah Agung berpendapat karena yang dengan tegas ditiadakan yaitu upaya hukum banding, maka peninjauan kembali upaya hukum luar biasa tidaklah dilarang, kecuali untuk arbitrase yang dengan tegas menyatakan dalam memeriksa banding arbitrase, Mahkamah agung memutus dalam tingkat pertama dan terakhir (Pasal 72 ayat 4 UU No. 30 tahun 1999).

Mengadili menurut hukum dalam kaitan sebagai pengertian normative dan pengertian sosiologis. Dari segi teori hukum tau filsafat hukum, hukum sebagai pengertian normatif bersandar pada ajaran positivisme seperti ajaran "reine rechtslehre" atau the pure theory of law" atau teori murni tentang hukum dari Hans Kelsen. Pandangan sosiologi tentang hukum didukung oleh aliran teori hukum secara sosiologi (sociological jurisprudence) di Eropa, teori sosiologi di pelopori Eugen Ehrlich yang memisahkan antara "law in book" dan "law in action" di Amerika Serikat di pelopori oleh Roscoe Pond yang memperkenalkan ungkapan "law as a tool of social engineering" (hukum sebagi sarana pembaharuan masyarakat).

Dari berbagai konsep diatas dapat disimpulkan beberapa patokan sebagai makna mengadili menurut hukum:

1. Mengadili menurut hukum merupakan salah satu asas mewujudkan Negara berdasarkan atas hukum, setiap putusan hukum harus mempunyai dasar hukum normatif dan procedural yang telah ada sebelum perbuatan melawan hukum atau pelanggaran hukum terjadi.

2. Hukum mengadili menurut hukum harus diartikan luas melebihi pengertian hukum tertulis dan tidak tertulis. Hukum dalam kasus atau keadaan tertentu meliputi pengertian-pengertian yang mengikat pihakpihak, kesusilaan yang baik, dan ketertiban umum (geode zeden en openbaar orde).

3. Hukum yang hidup dalam masyarakat adalah hukum yang dipertimbangkan dalam putusan hakim, tetapi tidak selalu harus diikuti, karena kemungkinan "the living law" justru harus dikesampingkan karena tidak sesuai dengan tuntunan sosial baru. 
4. Sesuai dengan tradisi hukum yang berlaku, hakim wajib mengutamakan perapan hukum tertulis, kecuali kalau akan menimbulkan ketidakadilan, bertentangan dengan kesusilaan, atau ketertiban umum. Hakim bukan mulut atau corong undang-undang, melainkan mulut atau corong keadilan.

\section{Hakim Harus Menegakkan dan Membentuk Hukum}

Uraian mengenai keadaan hukum tidak dimasukkan untuk membahas kaidah-kaidah hukum dengan positif yang berlaku yang biasanya dikaitkan dengan hukum-hukum peninggalan masa kolonial atau hukum lain yang ditinggalkan oleh zaman.

Keadaan hukum yang akan di uraikan adalah berkenaan dengan proses pembentukan hukum dalam kaitan dengan susunan kekuasaan yang berlaku.

Meskipun secara teoritik digambarkan aliran atau ajaran kesejarahan (Von Savigny) hukum iti sebagai suatu yang tumbuh atau didapatkan dalam pergaulan masyarakat, tidaklah menghilangkan kenyataan seperti pendirian kaum positivis (Jeramy Bentham), bahwa hukum juga lahir dari perbuatan penguasa, lebih-lebih dalam dunia modern. Hukum menjadi salah satu produk penting kekuasaan.

Hal ini terjadi bukan semata-mata karena dorongan kekuasaan untuk mengatur, atau karena kepada kekuasaan diberi kekuasaan membentuk hukum, tetapi masyrakat sendiri menghendaki agar kekuasaan membentuk hukum. Kritikan terhadap DPR yang dianggap kurang produktif membentuk undangundang, merupakan cermin bahwa masyarakat menghendaki kekuasaan yang membentuk hukum, melainkan sebagai yang dilayani oleh hukum.

Wewenang membentuk hukum tidak hanya diberikan pada cabang kekuasaan legislatif. Kekuasaan administratif juga diberi kekuasaan membebtuk peraturan yang dibuat berdasarkan pelimpahan dari badan legislatif (delegated legislation). Bahkan terdapat kecendrungan yang menunjang cabang kekuasaan pembentuk undang-undang makin kendor atau paling kurang, berjalan tidak sebanding dengan kecepatan pembentukan hukum oleh administrasi negara (eksekutif). Demikian pula pembentukan hukum melalui hakim. Hakim-hakim bukan sekedar "bouche de la loi" tetapi menjadi penerjemah atau pemberi makna melalui penemuan hukum (rechtsvinding) bahkan menciptakan hukum baru (rechtscheeping) melaui putusan-putusannya (judge made law).

Hal-hal diatas menunjukan betapa eratnya hubungan antar hukum dengan kekuasaan. Hukum bukan suatu bentuk kegiatan kekuasaan, melainkan suatu fungsi kekuasaan.

Baik secara teoritik atau praktek, dikenal berbagai corak dan sifat kekuasaan. Kekuasaan senantiasa berjalan atau dijalankan sesuai dengan kehendak yang menjalankn kekuasaan, yang pada gilirannya dipengaruhi oleh aliran pikiran bhkn ideologi tertentu, atau pandangan keagmaan tertentu. Atau mungkin juga dibnagun karena hasrat berkuasa atau sesuatu kepentingan belaka. 
Berbagai landasan, corak, dan bersifat kekuasaan tersebut akan mempengaruhi bhkan menentukan isi hukum yang dibuat. Berdasarkan landasan, corak, dan sifat kekuasaan hukum dapat menjelma sebagai sematamata instrumen kekuasaan, bukan sebagai instrumen kepentingan rakyat.

Pembentukan hukum dalam satu sistem kediktatoran atau totaliter akn sangat berbeda dengan pembentukan hukum dalam suatu tataan demokrtis, baik dalam proses maupun isinya. Dalam tatanan demokrasi, pertisipasi rakyat secara bebas dalam pembentukan hukum merupakan suatu esensi yang tidak mungkin di abaikan. Sebaliknya dalam sistem kediktatoran atau otoriter, partisipasi rakyat secara bebas merupakan suatu yang ditabukan. Demikian pul dalam sistem kekuasaan yang terlalu berpihak pada kepentingan tertentu, akan menghasilkan hukum sesuai dengan kepentingan tersebut.

Kita masih dapat memperpanjang kenyataan hubungan antara hukum dengan kekuasaan. Namun, gambaran diatas cukup membuktikan bahwa hukum sebagai produk kekuasaan tidak pernah terlepas dari kehendak, kepentingan atau dasar-dasar kekuasaan itu sendiri. Disinilah sesungguhnya asal mula permasalahan hukum yang adil atau tidak adil, bermanfaatan atau tidak bermanfaat, memuaskan atau tidak memuaskan, baik bagi individu atau masyarakat secara keseluruhan.

Dengan demikian ditinjau dari proses pembentukan hukum yang dikaitkan dengan sifat, dan corak kekuasaan, hukum bak pedang dua. Hukum bukn semata-mata instrumen social, tetapi juga sebagai instrumen kekuasaan.

Harus diakui bahawa dalam setiap sistem kekuasaan pasti ada hukum sebagai instrumen untuk menjalankan kekuasaan. Masalah akan timbul pada kekuasaan itu tidak mempunyai pertalian atau dipertalikan dengan masyarakat, melainkan dengan kepentingan kekuasaan belaka. Disini hukum dibuat demi dan sebagai alat penyelenggara kekuasaan dan tidak jarang bersebrangan dengan kepentingan rakyat banyak. Dalam suasana seperti ini, benrlah ungkapan untuk pandangan yang menyatakan hukum semata-mata alat berkuasa untuk menindas rakyat banyak (Marxisme). Hukum semacam ini tidak akn mencerminkan kepentingan atau memberi manfaat terutama dalam makna hukum yang adil. Karena itu betapa pentingnya meletakkan dasar-dasar proses pembentukan hukum dalam satu tatanan kekuasaan yang bertalian atau dipertalikan dengan kepentingan rakyat banyak. Selanjutnya dapat pula disebutkan, mengingat hukum itu sekedar suatu produk, tidak pula berlebihan apabila dikatakan bahwa sistem, corak, dan sifat kekuasaan merupakan pra kondisi yang harus ada sebagai dasar menciptakan dan menegakkan hukum yang adil atau berkeadilan.

Dalam rangka menegakkan aturan-aturan hukum yang berlaku, maka diperlukan adanya suatu institusi negara yang dinamakan kekuasaan kehakiman (Judicative power). Kekuasaan kehakiman dalam praktek diselenggarakan oleh badan-badan peradilan negara. Adapun tugas pokok badan peradilan terutama tugas dibidang judicial, yaitu dalam rangka memeriksa, mengadili, memutuskan dan menyelesaikan perkara-perkara yang diajukan oleh masyarakat pencari keadilan. 


\section{Hakim Haruslah sebagai Penegak Hukum yang Adil}

Menegakkan keadilan bukanlah sekedar menjalankan prosedur formal dalam peraturan hukum yang berlaku di suatu masyarakat, setidaknya itulah pernyataan yang kerap dicetuskan oleh Moh. Mahfud MD, Ketua Mahkamah Konstitusi Republik Indonesia. Menurut Mahfud menegakkan nilai-nilai keadilan lebih utama dari pada sekedar menjalankan berbagai prosedur formal perundang-undangan yang acap kali dikaitkan dengan penegakan hukum. ${ }^{43}$ Tekad Mahkamah Konstitusi semacam itu bahkan ditegaskan dalam situsnya, yaitu "mengawal demokrasi dan menegakkan keadilan substantif". Beberapa terobosan hukum yang dilakukan oleh Mahkamah Konstitusi yang lebih mengutamakan keadilan substantif dibanding keadilan formal-prosedural diantaranya adalah saat Mahkamah Konstitusi membolehkan penggunaan KTP dengan sejumlah syarat tertentu dalam pemilu oleh warga yang tidak terdaftar dalam Daftar Pemilihan Tetap (DPT). Di samping iti Mahkamah Konstitusi dalam persidangan judicial review pernah membuka rekaman hasil penyadapan KPK terhadap percakapan Anggodo yang kemudian membuka tabir adanya "markus" dalam proses penegakan hukum. ${ }^{44}$

Keadilan merupakan salah satu tujuan dari setiap sistem hukum, bahkan merupakan tujuannya yang terpenting. Masih ada tujuan hukum yang lain yang juga selalu menjadi tumpuan hukum, yaitu kepastian hukum, kemanfaatan dan ketertiban. Disamping tujuan hukum, keadilan juga dapat dilihat suatu nilai (value). Bagi suatu kehidupan manusia yang baik, ada empat yang merupakan fondasi pentingnya, yaitu: (1) keadilan, (2) kebenaran, (3) hukum dan (4) moral. Akan tetapi dari keempat nilai tersebut, menurut filosof besar bangsa Yunani, yaitu plato, keadilan merupakan nilai kebajikan yang tertinggi. Menurut Plato: "Justice is the supreme virtue which harmonize all other virtues,

Para filosof Yunani memandang keadilan sebagai suatu kebajikan individual (individual virtue). Oleh karena itu dalam Institute of Justinian, diberikanlah definisi keadilan yang sangat terkenal itu, yang mengartikan keadilan sebagai tujuan yang kontinyu yang konstan untuk memberikan kepada setiap orang haknya. "Justice is the Constant and continual purpose which gives to everyone his own". 46

\footnotetext{
${ }^{43}$ Lihat artikel, Menegakkan Keadilan Jangan Sekedar Menegakkan Hukum, dalam situs <http://erabaru.net/opini/65-opini/1009-menegakkan-keadilan-jangan-sekedarmenegakkan-hukum>, diakses tanggal 3 November 2012.

${ }^{44}$ Bambang Sutiyoso, "Reformasi Keadilan dan Penagakan Hukum di Indonesia", (Yogyakarta: UII Press, 2010), hal. 3- 4.

${ }^{45}$ Roscoe Pound sebagaimana dikutip Munir Fuady, "Aliran Hukum Kritis Paradigma Ketidakberdayaan Hukum”, (Bandung: Citra Aditya Bakti, 2003), hal. 52.

${ }^{46}$ Ibid., hal. 53.
} 
Apabila dicermati para hakim di Indonesia pada umumnya tidak menganut prinsip the binding force of precedent sebagaimana dianut negaranegara Anglosaxon, oleh karena itu otoritas dari majelis hakim menjadi begitu besarnya dalam memutuskan perkara. Akibatnya kemudian banyak terjadi disparitas dalam putusan perkara yang sejenis. Hal ini di tandai dengan adanya perbedaan secara substansial yang tajam antara produk hukum berupa putusan pengadilan yang satu dengan pengadilan yang lain atau putusan yang dibuat oleh hakim Pengadilan Negeri, hakim Pengadilan Tinggi, dan hakim Mahkamah Agung mengenai suatu perkara hukum yang sama, padahal semuanya mengacu pada peraturan yang sama.

Dalam mewujudkan keadilan yang subtantif dalam peradilan yang diskursus konsep keadilan (justice), banyak ditemukan berbagai pengerian keadilan, diantaranya keadilan adalah menempatkan sesuatu pada tempatnya (proporsional); keadilan adalah keseimbangan antara hak dan kewajiban dan lain sebagainya. Demikian pula klasifikasi keadilan juga banyak ditemukan, misalnya Aristoteles membagi keadilan komutatif dan distributif, ada juga membedakan norm gerechtigkeit dan einzelfall gerechtigkeit dan seterusnya. Demikian ada ahli yang menjadi : keadilan hukum (legal justice), keadilan secara moral (moral justice) dan keadilan sosial (social justice).

Dalam konteks putusan hakim peradilan, terutama yang sering disinggung-singgung adalah berupa keadilan prosedural (procedural justice) dan keadilan substantif (substantive justice). Dalam hal ini kami mencoba memberi batasan apa yang dimaksud dengan keadilan prosedural dan keadilan substantif ini. Keadilan prosedural adalah keadilan yang didasarkan pada ketentuan-ketentuan yang dirumuskan dari peraturan hukum formal, seperti mengenai tenggat waktu maupun syarat-syarat beracara di pengadilan lainnya. Sedangkan keadilan substantif adalah keadilan yang didasarkan pada nilai-nilai yang lahir dari sumber-sumber hukum yang responsif sesuai hati nurani. ${ }^{47}$

Adanya benturan-benturan antara pemenuhan keadilan prosedural di suatu sisi dan keadilan substantif di sisi lain, memang harus selalu ada solusi dan opsi yang jelas dan harus diputuskan oleh hakim dengan argumentasi hukum yang dapat dipertanggung jawabkan. Dalam hal ini kami berpendapat, semestinya hakim lebih dahulu mengedepankan pilihan keadilan substantif, yang sesuai dengan hati nurani dan rasa keadilan masyarakat. Oleh karena itu hanya dalam hal-hal kasuistis dan sangat eksepsional, yaitu terjadi pertentangn yang tajam antara keadilan prosedural dan keadilan substantif, keadilan prosedural bisa diabaikan. Akan tetapi, tentunya tidak berarti semua kasus harus boleh begitu saja keadilan prosedural dikalahkan. Hal ini untuk menghindari apa yang dikemukakan oleh Machiavelli, yaitu dihalalkannya segala cara untuk mencapai tujuan. Tau dengan kata lain jangan sampai keadilan prosedural diabaikan begitu saja untuk mencapai tujuan tertentu yang sebenarnya tidak terlalu essensial pemenuhannya.

\footnotetext{
${ }^{47}$ Bambang Sutiyoso. Op. Cit., hal. 7- 9.
} 
Meskipun demikian antara keadilan prosedural dan keadilan substantif semestinya tidak dilihat secara dikotomi, tetapi ibarat dua sisi mata uang yag saling erat satu sama lain. Oleh karena itu dalam keadaan normal, mestinya keadilan prosedural dan keadilan substantif harus dapat disinergikan dan di kompromikan, keadilan substantiflah yang perlu didahulukan. Dengan demikian, mestinya penegakan substantif juga harus bersifat selektif kasuistik dengan didukung argumentasi hukum yang dapat dipertanggungjawabkan. ${ }^{48}$

Yang saya maksud disini adalah lingkungan sosial tempat hukum berlaku dan ditegakkan. Selama ini persoalan penegakkan hukum yang benar dan adil selalu diserahkan pada pelaku penegakan hukum. Pelaku penegak hukum di tuntut menjadi penegak hukum yang benar dan adil.

Penegakan hukum tidak berada pada suatu wilayah yang kosong, penegakan hukum terjadi dan berlaku ditengah-tengah masyarakat. Lebih jauh perlu dimengerti bahwa penegakan hukum bukan sekedar berada ditengahtengah masyarakat melainkan dapat dipengaruhi oleh keadaan dn interaksi sosial yang terjadi dalam masyarakat. Dalam suatu masyarakat yang memelihara atau mengembangkan sistem hak-hak privilege berdasarkn status, atau suatu masyarakat dengan pebedaan yang tajam antara "the have" dan "the have not", atau suatu masyarakat yang berbeda dalam lingkungan kekuasaan otoriter, akan menemoatkan sistem penegakan hukum yang berbeda dengan masyarakat yang terbuka dan egaliter.

Penegakan hukum yang benar dan yang adil tidak semata-mata ditentukan oleh kehendak pelaku hukum sebagai "ratu adil" tetapi juga kemauan dan kemampuan masyarkat untuk berupaya memperoleh perlakuan hukum yang benar dan adil. Dengan kata lain penegakan hukum yang adil ditentukan juga oleh kesadaran dan partisipasi masyarakat, bukan semata-mata keinginan pelaku penegakan hukum.

Dari kenyataan yang ada, ada dua aspek sosial yang menghambat penegakan hukum yang benar dan adil. Pertama, bersumber dari rasa takut atau apitesme masyarakat untuk membela keadilan bagi diri sendiri maupun lingkungannya. Hal ini dapat terjadi karena susunan masyarakatyang menjelmakan sikap serba menerima kehendak penguasa, atau karena sistem penindasan yang menghilangkankeinginan atau keberanian untuk berjuang atau membela kepentingannya. Kedua, terutama semenjak masa reformasi, di dapati berbagai tekanan publik yang acap kali berlebihandalam penegakan hukum. Pendapat atau pendangan politik memang sangat penting untuk mencegah kesewenang-wenangan atau penyalahgunaan kekuasaan dalam penegakan hukum. Tetapi yang harus dijaga adalah jangan sampai pendapat atau pendangan tersebut menjadi suatu tekanan yang merendahkan atau menimbulkan rasa takut pelaku penegakan hukum. Apabila hal semacam ini terjadi maka penegakan hukum yang benar dan adil akan sama jauhnya dengan penegakan hukum dalam suatu masyarakat yang selalu berserah diri dengan kehendak kekuasaan. Publik yang menghendaki penegakan hukum yang benar

\footnotetext{
${ }^{48}$ Ibid., hal.12-13.
} 
dan adil harus menerima syarat untuk melakukannya dengan cara-cara yang benar dan adil juga. Publik yang menghakimi sendiri suatu peristiwa pelanggaran hukum bukanlah cara penegakan hukum secara adil dan benar, melainkan kekejaman yang melanggar hukum.

\section{Keadilan menurut Pancasila}

Persepsi yang keliru dalam memahami makna penegakan hukum yang lebih berorientasi pada asas legalitas formal, tidak sejalan dengan karakteristik peradilan Indonesia yang berbasis pada tiga aspek sumber hukum yaitu ilmu pengetahuan (doktrin) hukum, nilai-nilai kebiasaan atau budaya luhur masyarakat lokal dan nilai-nilai religius. ${ }^{49}$ Berdasarkan rumusan kesimpulan seminar hukum nasional ke-IV/1994, dinyatakan bahwa perlu dikembangkan gagasan kualitas pemberian keadilan (the dispension of justice) yang lebih cocok dengan hukum pancasila. Pernyataan tersebut menyiratkan perlunya dikembangkan keadilan bercirikan Indonesia, yaitu Keadilan Pancasila, yang mengandung makna "keadilan berketuhanan, keadilan berkemanusiaan (humanistik), keadilan yang demokratik, nasionalistik, dan berkeadilan sosial. Ini berarti keadilan yang di tegakkan tidak sekedar keadilan formal, tetapi juga keadilan substansial. ${ }^{50}$ Apabila bertolak dari pancasila dalam menciptakan sistem hukum yang bercirikan indonesia (distinctly Indonesian) maka pikiranpikiran serta pendekatan indonesia dapat diajukan sebagai alternatif. Salah satu kemungkinan yang dapat diajukan sebagai doktrin atau asas alternatif, bahwa Indonesia lebih mengunggulkan asas supremacy of moral/justice daripada asas Supremacy of $l a w^{51}$. Oleh karena itu, penerapan asas legalitas dalam KUHP dalam konteks ke-Indonesiaan (sistem hukum nasional) jangan diartikan semata-mata kepastian/kebenaran/keadilan formal undang-undang tetapi lebih menukik pada kepastian/ kebenaran/ keadilan nilai-nilai substantif. ${ }^{52}$

Dalam menegakkan hukum, hakim juga harus berpedoman diri pada pancasila dan UUD 1945 yang merupakan ruh/ penentu arah. Dengan demikian dalam penegakan hukum, hakim harus sesuai Grand design sistem dan politik hukum nasional yang mestinya tetap berdasarkan pada paradigma Pancasila, yaitu:

1. Paradigma Ketuhanan (moral-religius);

${ }^{49}$ Suteki, "Integrasi Hukum dan Masyarakat", (Semarang: Pustaka Magister, 2007), hal. 60-61, 105. Lebih lanjut dikatakan bahwa pembangunan hukum di Indonesia di dasarkan tiga bahan dasar yaitu hukum islam (religiouswisdom), hukum adat (living law wisdom) dan hukum modern (state law), kenyataannya terkesan ada upaya sistematis menegaskan hukum adat, maka perlu di lembagakan kembali (re-institusionalization).

\footnotetext{
${ }^{50}$ Barda Nawawi Arif, Op. Cit., hal. 87.

${ }^{51}$ Suteki, Op. Cit., hal. $17-18$.

${ }^{52}$ Barda Nawawi Arif, Op. Cit., hal. 27.
} 
2. Paradigma Kemanusiaan (humanistik);

3. Paradigma Kebangsaan (persatuan/nasionalistik);

4. Paradigma kerakyatan/demokrasi,

5. Paradigma keadilan sosial.

Grand design ini menghendaki adanya keseimbangan ketiga nilai dasar yaitu:

1. Nilai Ketuhanan (moral-religius);

2. Nilai Kemanusiaan (humanistik);

3. Nilai Kemasyarakatan, yaitu: nasionalistik,demokratik dan keadilan sosial.

Disamping prinsip keseimbangan ketiga nilai dasar tersebut, grand design sistem dan politik hukum nasional juga harus didasarkan pada ide keseimbangan monodualistik, yaitu meliputi hal-hal sebagai berikut:

1. Antara "kepentingan umum/masyarakat" dan "kepentingan individu";

2. Antara perlindungan/ kepentingan pelaku (ide individualisasi pidana) dan korban;

3. Antara faktor objektif (perbuatan lahiriah) dan subjektif (orang/batiniah/sikap batin); $\rightarrow$ ide "daad-dader strafrecht",

4. Antara kriteria "formal" dan "material";

5. Antara kepastian hukum, kelenturan/ elastisitas/ fleksibilitas, dan keadilan;

6. Antara nilai-nilai nasional dan nilai-nilai global/internasional/universal;

Dalam penegakan hukum seharusnya hakim berpegang teguh pada prinsip bahwa hukum adalah untuk manusia, bukan manusia untuk hukum. Oleh karena itu, hakim harus senantiasa mengedepankan nilai keadilan dalam masyarakat, sehingga harus selalu mengikuti dinamika perubahan yang ada dalam masyarakat. ${ }^{53}$

Upaya penegakan hukum dan keadilan serta kepastian hukum yang adil menurut Pancasila mengandung "asas keseimbangan" dan bermakna kepastian substantif dan material (substantive/material certainty), tidak sekedar kepastian formal (formal/ legal certainty) sehingga diharapkan lebih bisa mengarah ke penegakan hukum pidana yang adil. ${ }^{54}$ Kepastian hukum dalam UUD 1945 lebih mengandung asas keseimbangan dan mengandung konsep integratif. ${ }^{55}$

${ }^{53}$ Siti Malikhatun Badriah, "Penemuan Hukum dalam Konteks Pencarian Keadilan", (Semarang: Badan Penerbit Undip, 2010), hal. 95-96.

${ }^{54}$ Lihat Barda Nawawi Arief, Op. Cit., hal. 13.

55 Istilah asas keseimbangan antara kepastian substantif (substantive certainty) dan kepastian formal (formal certainty) untuk menggambarkan maksud "kepastian hukum yang adil” menurut UUD 1945 dikemukakn oleh Barda Nawawi Arief, sedangkan istilah konsep Integratif dari UUD 1945 dikemukakan oleh M. Arief Amrullah untuk menggambarkan kepaduan antara prinsip keadilan dalam Rechtsstaat dengan prinsip keadilan the Rule of Law. 
Intinya lebih mengandung makna keadilan substantif tidak sekedar kepastian formal. $^{56}$

Uraian terdahulu menunjukan ada berbagai syarat yang harus dipenuhi untuk penegakan hukum yang adil dan berkeadilan:

Pertama, aturan hukum yang akan ditegakkan. Penegakan hukum yang adil atau berkeadilan akan tercapai apabila hukum yang akan ditegakkan demikian pula hukum yang mengatur cara-cara penegakan hukum, adalah benar dan adil. Suatu aturan hukum akan benar dan adil apabila dibuat dengan cara-cara yang benar dan materi muatannya sesuai dengan kesadaran hukum dan memberi sebesar-besarnya manfaat bagi kepentingan orang perorangan dan masyarakat banyak pada umumnya. Suatu aturan hukum akan tidak benar apabila hanya dibuat untuk kepentingan kekuasaan belaka dan mengandung kesewenang-wenangan. Tetapi perlu juga menjadi perhatian, suatu hukum dapat menjadi tidak benar dan tidak adil apabila mempunyai jarak begitu jauh dengan kesadaran dan kenyataan sosial yang berlaku sehingga masyarakat merasa asing atau terasing dari aturan hukum tersebut. Hal ini dapat terjadi karena hukum sudah sangat ketinggalan, atau karena terlalu jauh berada didepan sehingga dapat terjangkau oleh realitas sosial yang ada. Selanjutnya hukum dapat pula tidak benar dan tidak adil apabila pembuatannya tidak mengindahkan tata cara pembuatan yang baik (algemene beginselen van behoorlijk wetgeving), karena akan menimbulkan keadaan seperti keracunan dalam penerapan atau ketidak pastian hukum.

Kedua, pelaku penegakan hukum. Pelaku penegakan hukum dapatlah disebut sebagai kunci utama penegakan hukum yang adil dan berkeadilan. Di tangan penegak hukum, aturan hukum yang bersifat abstrak menjadi kongkrit. Secara sosiologi, inilah hukum yang sebenarnya terutama bagi pencari keadilan. Ada berbagai syarat yang harus dipenuhi agar dapat menegakkan hukum secara adil atau berkeadilan.

1. Perlakuan terhadap hukum yang akan ditegakkan. Ada tiga pilihan peranan yang dilakukan pelaku penegakan hukum dalam menegakkan hukum:

a. Pelaku penegakan hukum sekedar sebagai "la bouche de la loi" atau "spreekbuis van de wet". Dalam hal aturan hukum sudah jelas, penegakan hukum hanya bertindak sebagai corong peraturan, kecuali apabila penerapan itu akan menimbulkan ketidak adilan, bertentangan kesusilaan, atau bertentangan dengan suatu kepentingan atau ketertiban umum.

b. Pelaku penegakan hukum berlaku sebagai penterjemah (interpreter) suatu aturan hukum agar suatu aturan hukum menjadi instrumen keadilan. Hal ini dilakukan karena aturan hukum yang ada tidak sempurna, baik bahasa atau objek yang diaturnya tidak lengkap.

56 Kuat Puji Prayitno, "Rekonstruksi Pemikiran Hukum Pidana yang Integral", (Semarang: Badan Penerbit UNDIP, 2011), hal. 7-8. 
c. Pelaku penegakan hukum menjadi pencipta hukum (rechtschepping) dalam hal hukum yang ada tidak cukup mengatur atau didapati kekosongan hukum, atau sudah sangat tidak memadai sehingga tidak dapat lagi "ditambal" melalui penemuan makna hukum.

2. Memperhatikan kepentingan atau kebutuhan masyarakat, baik kebutuhan nyata maupun proyeksi kebutuhan di masa depan. Hukum adalah instrumen sosial untuk menjaga dan membangun masyarakat. Hukum tidak mengandung kesenjangan dengan kenyataan dan kecendrungan yang hidup dalam masyarakat. Penegakan hukum yang tidak mengindahkan berbagai kenyataan, akan dirasakansebagai sesuatu yang asing bahkan mungkin menekan masyarakat. Hal ini merupakan bentuk penegakan hukum yang tidak adil atau berkeadilan.

Ketiga, lingkungan sosial sebagai tempat hukum berlaku. Telah diutarakan "situation gebundenheit". Keadaan itu menentukan hukum baik dalam pembentukan maupun penegakannya, sangat dipengaruhi oleh kenyataan-kenyataan sosial, ekonomi, politik maupun budaya. Meskipun dalam situasi tertentu diakui hukum dapat berperan sebagi sarana pembaharuan, tetapidalam banyak hal hukum adalah cermin masyarakat. Telah dikemukakan tekanan publik terhadap penegakan hukum dapat mempengaruhi putusan penegak hukum. Begitupula kepentingan-kepentingan tertentu, seperti kepentingan ekonomi dan politik yang dominan dapat menentukan wujud penegakan hukum. Oleh sebab itu, perlu diciptakan berbagai persyaratan sosial yang kondusif agar penegakan hukum dapat dilakukan secara benar dan adil. Persyaratan itu antara lain; tumbuhnya prinsip egalitarian (keterbukaan) untuk menciptakan berbagai keseimbangan dalam perikehidupan masyarakat. Dalam berbagai perbedaan yang begitu tajam, baik sosial, ekonomi, politik dan lainlain, akan dialami kesulitan sistem penegakan hukum yang benar dan adil, karena hukum akan berpihak pada kekuatan-kekuatan dominan yang mungkin tidak berpihak pada kebenaran dan keadilan. Hukum yang benar dan adil hanya dapat berperan pada tatanan yang berkesinambungan dan tidak dalam tatanan ekstriminitas tertentu.

Demikianlah berbagai syarat untuk mencapai atau menciptakan penegakan hukum yang adil atau berkeadilan. Lebih lanjut perlu di jajaki : "Bagaimanakah wujud dari penegakan hukum yang adil dan berkeadilan?". Ada dua aspek terpenting untuk mencapai penegakn hukum yang adil dan berkeadilan, yaitu tatacara penegakan hukum (procedural justice) dan isi atau hasil penegakan hukum (substantive justice).

Sebenarnya keadilan bukanlah sesuatu yang baru. Persoalan keadilan ini telah hadir sejak manusia mengenal baik dan buruk. Pertanyaan-pertanyaan seperti mengapa ada kejahatan, mengapa ada penyakit dan kemiskinan, bahkan mengapa Tuhan menganugrahkan si A segala kenikmatan tetapi justru nenenggelamkan si B kedalam lautan kemiskinan dan penderitaan?, semua pertanyaan itu adalah wajr dan almiah.

Namun demikian tidak mudah memahami, apalagi menjelaskan persoalan ini, jika dikaitkan lagi dengan keadilan ilahi. Ini merupakan salah 
satu hal yang amat musykil, khususnya bila semua itu harus diukur dengan kepuasan nalar. Oleh karena itu, orang yang bijak dan dapat memahami kebijaksanaan dan keadilan Tuhan sering berkata: "Ada hikmah dibalik setiap peristiwa, baik yang dinilai sebagai ketidakadilan maupun yang dinilai sebagai keadilan sekalipun". 57

Menurut Mahfud MD, Keadilan berbasis nasionalisme adalah upaya menegakkan keadilan seperti bapak-bapak pendahulu bangsa; Soekarno, Hatta, Natsir, Wachid Hasyim, Radjiman Widyodiningrat, dan lainnya, yang mempertaruhkan nyawa untuk kemerdekaan indonesia. Ancaman bagi nasionalisme kita sekarang ini adalah mafia hukum dan ketidak adilan. Kalau hukum tidak ditegakkan dengan baik, maka kehancuran akan melanda kita. Kalau keadilan sudah tidak lagi menjadi sukma dalam kegiatan pemerintahan kita, maka pastilah ada ancaman atas eksistensi negara ini. Negara ini bisa hancur kalau hukum dan keadilan tidak ditegakkan karena ketidakadilan akan meluturkan nasionalisme dan menjadi pendorong timbulnya pembangkangan atas otoritas negara.

Nasionalisme sekarang ini haruslah berbasis keadilan (justice). Nasionalisme akan ambruk jika keadilan tidak tegak, pembangkangan (terhadap otoritas negara). ${ }^{58}$

Menurut Satjipto Rahardjo, meski mungkin jumlah orang-orang baik di negeri ini masih sedikit, namun umumnya mereka tidak muncul atau tidak bisa muncul. Mereka tidak bisa bermain menurut "kultur preman" sehingga tersisihkan menjadi kelompok pinggiran.

Istilah baik-baik disisni dipakai untuk menyebut mentalitas dan kualitas yang terpuji. Mereka itu antara lain Baharudin Lopa, Romo YB Mangunwijoyo (alm), dan lain-lain yang masih hidup. ${ }^{59}$

Hakim yang progresif menurut Satjipto Rahardjo, dimana pengadilan progresif mengikuti maksim, "hukum adalah untuk rakyat bukan sebaliknya". Bila rakyat adalah hukum, apapun yang dipikirkan dan dirasakan rakyat akan ditepis karena yang dibaca adalah kata-kata UU. Dalam hubungan ini, pekerjaan hakim menjadi lebih komplek. Seorang hakim bukan hanya teknisi UU, tetapi juga makhluk sosial. Ia bukan hanya memeras otak, tetapi juga nuraninya.

Menjadi makhluk sosial akan menempatkan hakim ditengah hiruk-pikuk masyarakat, keluar dari gedung pengadilan. Malah ada yang mengatakan seseorang hakim sudah tidak ada bedanya dengan wakil rakyat. Bila ia berada ditengah masyarakat, berarti ia berbagi suka-duka, kecemasan, penderitaan, harapan, seperti yang ada dimasyarakat. Melalui putusan-putusannya, hakim

\footnotetext{
${ }^{57}$ Ibid., hal. 37-38.

${ }^{58}$ Mahfud MD, “Kontroversi”, (Jakart: Konpress, 2012), hal. 212.

${ }^{59}$ Satjipto Rahardjo, "Penegakkan Hukum Progresif”, (Jakarta: Kompas, 2010), hal.
} 147. 
suka disebut mewakili suara mereka (rakyat) yang tak terwakili (unrepresented) dan kurang terwakili (under-represented).

Hakim yang berpikiran progresif, menjadikan dirinya bagian masyarakat, akan selalu menanyakan, apakah peran yang bisa saya berikan dalam masa reformasi ini? Apa yang diinginkan bangsa saya dengan reformasi ini? Dengan demikian, ia akan menolak bila dikatakan pekerjaannya itu hanya mengeja UU. Hakim progresif akan selalu meletakkan telinga ke degup jantung hati rakyatnya. $^{60}$

\section{Penutup}

Dalam wacana akedemik maupun politik hukum dikenal fungsi hakim sebagai pembaru hukum, dalam fungsinya yang demikian hakim bukan sekedar menerapkan aturan tapi lebih menukik lagi menemukan dan menciptakan hukum. Keyakinan hakim adalah sebuah ruang yang harus dibangun, dikembangkan, dan dilaksanakan sebagai ornamen ilmu dan agama dalam upaya pencari keadilan substantif. Penegakkan etika dan profesi hukum hakim, sebagai profesi luhur atau yang mulia (officium nabile) harus mempunyai kemampuan teknis/ profesionalisme (technical aspect). Penegakan etika profesi hukum hakim juga harus dilandasi suka cita hukum pancasila (Ground Norm) dimana nilai-nilai Ketuhanan Yang Maha Esa menjadi sebuah konsepsi dasar filosof disetiap jati diri hakim itu sendiri, dimana juga konsep keadilan sosial dalam Pancasila harus di akselerasikan dalam bentuk keputusan yang adil (keadilan substantif). Hakim yang baik itu dilahirkan dari dirinya sendiri yang mempunyai nilai dan norma jati diri bangsa dari segala aspek ketuhanan, bukan dibentuk oleh sistem dan rekrutmen serta doktrin-doktrin diluar kaidah Pancasila dan UUD 1945.

Pembentukan hakim juga harus dimulai dari rekrutmen yang mengedepankan prinsip objektif, transparansi, akuntabilitas, kompetensi, serta terbuka dan bersih dari segala bentuk korupsi, kolusi dan nepotisme.asas keadilan berdasarkan ketuhanan yang Maha Esa merupakan asas yuridis karena tercantum secara tegas dalam UU, oleh karena itu menegakkan hukum pidana harus didasari pada tuntutan UU yang juga berdasarkan ketuhanan yang Maha Esa. Pendeketan yuridis - religius sebagai karakter dalam peradilan. Kebebasan hakim dalam memutus perkara pidana yang ditinjau dari keadilan substantif, mewujudkan keadilan hakim untuk menggali, mengikuti, dan memahami nilai-nilai hukum dan rasa keadilan yang hidup dalam masyarakat dalam bingkai norma-norma agama yang berketuhanan yang Maha Esa. Yang juga diperlukan adalah peningkatan serta pendidikan mental, intelektual, kecerdasan spiritual dan emosional hakim melalui pendidikan dan pelatihan secara berkala dan terus menerus.

\footnotetext{
${ }^{60}$ Ibid., hal. 191-192.
} 


\section{Daftar Pustaka}

Adji, Oemar Seno. Peradilan Bebas Negara Hukum, Jakarta: Erlangga, 1980.

Arief, Barda Nawawi. Pendekatan Keilmuan dan Pendekatan Religius dalam rangka Optimalisasi dan Reformasi Penegakan Hukum (Pidana) di Indonesia, Semarang: Badan Penerbit UNDIP, 2007.

Asrun, A. Muhammad. Krisis Peradilan: Mahkamah Agung di bawah Suharto, Jakarta: ELSAM, 2004.

Assidhiqie, Jimly. dalam Luhut Pangaribuan, Lay Judges \& Hakim Ad Hoc, Studi Teoritis mengenai Sistem Peradilan Pidana Indonesia, (Jakarta: Penerbit Papas Sinar Sinanti, 2009.

Badriah, Siti Malikhatun. Penemuan Hukum dalam Konteks Pencarian Keadilan, Semarang: Badan Penerbit Undip, 2010.

Bertens, K. Etika, Jakarta: Gramedia Pustaka Utama, 2000.

Djohansjah, J. Reformasi Mahkamah Agung Menuju Independensi Kekuasaan Kahakiman, dalam Luhut Pangaribuan. Lay Judges \& Hakim Ad Hoc, Studi Teoritis Mengenai Sistem Peradilan Pidana Indonesia, (Jakarta: Fakultas Pascasarjana Universitas Indonesia, 2009.

Frankena, William K. Ethics, New Jersey: Prentice-Hall, 1963.

Harahap, Yahya. Kedudukan Kewenangan dan Acara Peradilan Agama, Bandung: Sinar Grafika, 1996.

Khadduri, Majjid. The Islamic Conception of Justice, (Baltimore and London: The Johns Hopinks University Press, 1984.

Kymlicka, Will. Contemporary Political Philosophy. An Introduction, Clarendon Press. Oxford. 1990.

Labacqz, Karen. Teori-teori Keadilan Six Theories Of Justice, Bandung: Nusa Media, 2011.

Madjid, Nurcholis. Islam Kemanusiaan dan Keoderenan, Doktrin Peradaban, Sebuah Telaah Kritis Tentang Masalah Keimanan, Cetakan kedua, Jakarta: Yayasan Wakaf Peradaban, 1992.

Mahfud MD. Kontroversi, Jakarta: Konpress, 2012.

Mahmutatom HR. Rekonstruksi Konsep Keadilan, Semarang: Badan Penerbit UNDIP, 2009.

Mertokusumo, Sudikno. Bunga Rampai Ilmu Hukum, Yogyakarta: Liberty, 1984.

Mill, JS., dan John Rawl. Teori-teori Keadilan Analisis Kritis terhadap Pemikiran, Bandung: Nusa Media, 2001.

Muchsin. Kekuasaan Kehakiman yang Merdeka dan Kebijakan Asasi, (Jakarta: Penerbit STIH IBLAM, 2004. 
Notohamidjojo, Masalah Keadilan, Semarang: Tirta Amerts, 1971.

Prayitno, Kuat Puji. Rekonstruksi Pemikiran Hukum Pidana yang Integral, Semarang: Badan Penerbit UNDIP, 2008.

Pound, Roscoe. sebagaimana dikutip Munir Fuady, Aliran Hukum Kritis Paradigma Ketidakberdayaan Hukum, Bandung: Citra Aditya Bakti, 2003.

Rahardjo, Satjipto. Penegakan Hukum Progresif, Jakarta: Penerbit Kompas, 2010.

, Hukum dalam Jagat Ketertiban, Jakarta: UKI Press, 2006.

-, Penegakkan Hukum Progresif, Jakarta: Kompas, 2010.

Rasuanto, Bur. Keadilan Sosial, Pandangan Deontologis Rawls dan Habermas Dua Teori Filsafat Modern, Jakarta: Gramedia Pustaka Utama, 2005.

Sudarto, Hukum Pidana dan Perkembangan Masyarakat, Kajian Terhadap Pembaharuan Hukum Pidana, Bandung: Sinar baru. Bandung, 1983.

Sudirman, Anatonius. Hati Nurani Hakim dan Putusannya, Bandung: Citra Aditya Bhakti, 2007.

Suseno, Frans Magnis. Etika Dasar, Masalah-masalah Pokok dalam Filsafat Moral, Yogyakarta: Penerbit Kanisius, 1985.

Magister, 2007.

Sutiyoso, Bambang. Metode Penemuan Hukum, Upaya Mewujudkan Hukum Yang Pasti Dan Berkeadilan, Yogyakarta: UII Press, 2006.

Reformasi Keadilan dan Penagakan Hukum di Indonesia, Yogyakarta: UII Press, 2010.

Ujan, Andre Atta. Filsafat Hukum, Membangun Hukum, Membela Keadilan, Yogyakarta: Pustaka Filsafat. Kanisius, 2009.

\section{Internet}

Mahfud MD <http//www.voa-islam.com/news/Indonesia>, diakses tanggal 8 Januari 2013. November 2012.

Menegakkan Keadilan Jangan Sekedar Menegakkan Hukum, dalam situs <http://erabaru.net/opini/65-opini/1009-menegakkan-keadilan-jangansekedar-menegakkan-hukum>, diakses tanggal 3 November 2012. 


\section{Makalah}

Basic Prinsiples on the Independence of the Judiciary, Seventh United Nation Conggress on the Prevention of Crime and the Treatment of offender held at Milan from 26 August to 6 September 1985 and endorse by General Assembly Resolutions 40/30 of 29 November 1985 and 40/146 of 13 Desember 1985.

Lotulung, Paulus Efendi. Kebebasan Hakim dalam Sistem Penegakan Hukum. Makalah dalam Seminar Pembangunan Hukum Nasional VIII, BPHN. Denpasar, Bali, 2003.

Suteki. Kebijakan Tidak Menegakan Hukum (Non Enforcement of Law), demi Pemuliaan Keadilan Substantif. Naskah Pidato Pengukuhan Penerimaan Guru Besar dalam Ilmu Hukum Fakultas Hukum UNDIP. Semarang. 2010 .

The Bangalore Principle of Judicial Conduct, The Bangalore Draft Code of Judicial Conduct 2001 adopted by Judicial Group on the Strengthening Judicial Integrity, as revised at the Round Table Meeting Of Chief Justices held at the Peace Palace, The Hague, November 25 - 26, 2002. 